\title{
Bismuth, lead-bismuth and lead-antimony sulfosalts from the granite-hosted hydrothermal quartz veins at the Elisabeth mine, Gemerská Poloma, Spišsko-gemerské rudohorie Mts., Slovakia
}

\author{
Martin ŠTEVKO ${ }^{1,2 *}$, Jiří SEJKORA ${ }^{2}$ \\ ${ }^{1}$ Earth Science Institute, Slovak Academy of Sciences, Dúbravská cesta 9, 84005 Bratislava, Slovak Republic; \\ martin.stevko@savba.sk \\ ${ }^{2}$ Department of Mineralogy and Petrology, National Museum, Cirkusová 1740, 19300 Prague 9, Czech Republic \\ * Corresponding author
}

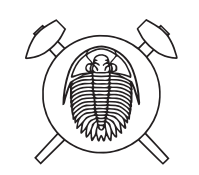

An interesting assemblage of bismuth and complex lead-bismuth and lead-antimony sulfosalts have been identified in
samples from hydrothermal quartz veins hosted in S-type granitic rocks at the Elisabeth mine near Gemerská Poloma,
Slovakia. We provide the first detailed study of the chemical composition of sulfosalts from the hydrothermal veins
directly related to the specialized ( $\mathrm{Sn}$-W-F enriched) Gemeric granites. Bismuthinite derivates (bismuthinite and phases
with $n_{\text {aik }}$ ranging from 21.3 to 23.7 and 30.3 ), minerals of the kobellite-tintinaite series (with $\mathrm{Sb} /(\mathrm{Sb}+\mathrm{Bi}$ ) atomic ratio
ranging considerably between 0.13 and 0.71 ), giessenite-izoklakeite series (with $\mathrm{Sb} /(\mathrm{Sb}+\mathrm{Bi}$ ) from 0.26 to 0.33 ) as
well as Pb-Sb sulfosalts (mainly jamesonite, boulangerite, robinsonite and their Bi-rich varieties) are common. Rare
Bi-enriched rouxelite, bournonite and minerals of the tetrahedrite group were also observed. The two distinct types of
sulfosalts associations were distinguished, each related to the different type of host rock and with variable Bi/Sb ratio.
The first is represented predominantly by Bi-rich sulfosalts (bismuthinite derivates, kobellite, giessenite-izoklakeite) and
occurs in the quartz veins hosted in P-enriched leucogranite. The second association is developed only in hydrothermal
quartz veins hosted in porphyric granites and except of Bi (bismuthinite derivates) also significant amounts of Sb-rich
sulfosalts (tintinaite, boulangerite, robinsonite, jamesonite, rouxelite, bournonite and tetrahedrite-( $\mathrm{Zn}$ ) to tetrahedrite-
(Fe)) are present.

Keywords: sulfosalts, bismuthinite derivates, kobellite homologous series, rouxelite, S-type granite, Gemerská Poloma

Received: 26 May 2021; accepted: 1 October 2021; handling editor: J. Zachariáś

The online version of this article (doi: 10.3190/jgeosci.328) contains supplementary electronic material.

\section{Introduction}

The greisens, albitites and hydrothermal quartz veins related to specialized S-type Gemeric granites were intensively explored for Sn, W, Mo, Nb, Ta and Li. Even though several interesting mineral associations were discovered (e.g., Malachovský et al. 1997, 2000; Petrík et al. 2011; Števko et al. 2015, 2018; Radvanec and Gonda 2019), the sulfidic ore mineralization and especially sulfosalts were never studied in detail. There are only scattered reports about occurrence of bismuthinite, cosalite, jamesonite, emplectite, tetrahedrite and garavellite from greisens and related hydrothermal quartz veins at the Medvedí potok Sn-W-Mo deposit near Hnilec (Drnzíková and Mandáková 1982; Radvanec and Gonda 2019). Malachovský (1983) described the occurrence of bismuthinite, kobellite, Bi-rich jamesonite and Bi-rich boulangerite from greisens and hydrothermal quartz veins hosted in granite from Dlhá dolina near Gemerská Poloma.

This paper is focused on the detailed mineralogical characterization of recently discovered association of bismuth, lead-bismuth and lead-antimony sulfosalts from the hydrothermal quartz veins hosted in a hidden intrusion of S-type Gemeric granites at the Elisabeth mine near Gemerská Poloma. New data on the chemical composition of minerals of the bismuthinite-aikinite series, kobellite homologous series, $\mathrm{Pb}-\mathrm{Sb}$ sulfosalts and rouxelite as well as their paragenetic relations are presented.

\section{Geological setting}

The hydrothermal quartz veins with sulfosalts, sulfides, carbonates and phosphates are hosted in the hidden intrusion of specialized Gemeric granites, which was recently uncovered during the excavation of Elisabeth adit at the Gemerská Poloma talc deposit, located about $10 \mathrm{~km}$ northwest of Rožňava town, Spišsko-gemerské rudohorie Mts., Slovak Republic [GPS 48 $45^{\prime} 4.07^{\prime \prime} \mathrm{N}$ and $20^{\circ} 29^{\prime} 39.32 " \mathrm{E}$ ].

The granitic rocks of the Gemeric Unit represent a distinct type of specialized (Sn-W-F), highly evolved suite with S-type affinity that differs from other granitoids occurring in the Veporic and Tatric Units of the Western Carpathian crystalline basement. Besides fluorine, they 


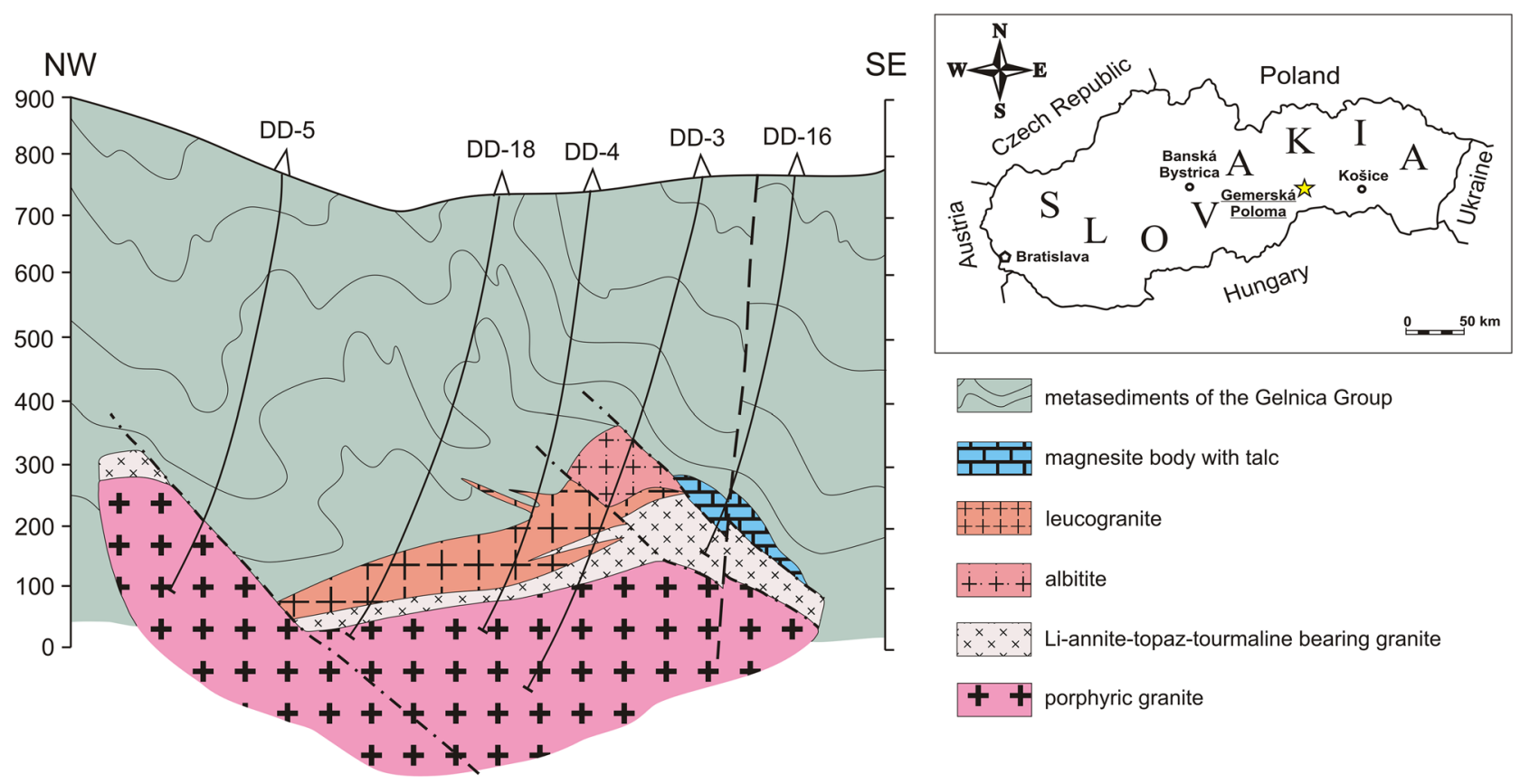

Fig. 1 Cross section of the granite pluton and talc deposit near Gemerská Poloma (modified after Dianiška et al. 2002).

are enriched in phosphorus and rare lithophile elements, such as Li, Rb, Cs, B, Ga, Sn, W, Nb, Ta, U and depleted in REE, Zr, Ti, Sr, Ba (e.g., Uher and Broska 1996; Petrík and Kohút 1997; Broska and Uher 2001; Kubiš and Broska 2005, 2010; Broska and Kubiš 2018; Villaseñor et al. 2021). Recent zircon U-Pb and molybdenite Re-Os isotopic dating indicate emplacement of the Gemeric granites and related post-magmatic mineralization during Late Permian ( 260 to 230 Ma; Poller et al. 2002; Kohút and Stein 2005; Radvanec et al. 2009; Villaseñor et al. 2021). Younger, Alpine (Cretaceous) fluid-driven lowtemperature tectono-metamorphic overprint affected the granitic rocks along mylonite zones (Breiter et al. 2015).

The Gemeric granitic rocks form several small plutons intruding the intensively folded Lower Paleozoic (mainly Ordovician to Devonian) volcano-sedimentary complex of the Gelnica Group metamorphosed under greenschist-facies metamorphic conditions (Bajaník et al. 1984; Petrasová et al. 2007). In the studied area, the metamorphic rocks are represented mainly by phyllites, metapyroclastic rocks of rhyolitic to dacitic composition, locally with bodies and lenses of metadolomite and strongly steatitized magnesite. The latter has been recently exploited by Elisabeth mine as a talc deposit near Gemerská Poloma (Kilík 1997; Radvanec et al. 2004; Petrasová et al. 2007). Several types of granites were distinguished in the studied area (Fig. 1): (a) coarsegrained porphyric granite to granite porphyry, (b) mediumgrained Li-annite-topaz-tourmaline bearing granite, (c) P-enriched topaz-zinnwaldite leucogranite and (d) albitite (Dianiška et al. 2002, 2007; Breiter et al. 2015). Except for the albitites, all listed types of granitic rocks were recently found in the Elisabeth adit (Števko et al. 2015, 2018).

The hydrothermal quartz veins with sulfosalts were observed in all types of granitic rocks but are especially common in porphyric granites and P-enriched leucogranite. They are generally up to $15 \mathrm{~cm}$ thick and up to $3 \mathrm{~m}$ long. Besides sulfosalts, they contain variable amounts of albite, muscovite, Li-bearing micas, chlorites, rutile, fluorite, polycrase-(Y) to uranopolycrase, bastnäsite-(Ce), carbonates (Mn-rich siderite, rhodochrosite, calcite and dolomite), phosphates (fluorapatite, triplite, fluorarrojadite-(BaNa), fluorarrojadite-(BaFe), fluordickinsonite(BaNa) and viitaniemiite) and sulfides like pyrite, arsenopyrite, sphalerite, chalcopyrite and minor galena (Uher et al. 2009; Števko et al. 2015, 2018, 2020).

\section{Analytical methods}

The samples with sulfosalts were systematically (period of 2009-2018) collected at the dumps of Elisabeth mine from the hydrothermal quartz veins hosted in various types of granitic rocks.

Quantitative chemical analyses of sulfosalts were performed on a Cameca SX100 electron microprobe (Department of Mineralogy and Petrology, National Museum, Prague, Czech Republic), operating in the wavelength-dispersive (WDS) mode $(25 \mathrm{kV}, 20 \mathrm{nA}$ and 2 to $5 \mu \mathrm{m}$ wide beam). The following standards and $\mathrm{X}$-ray lines were used (DL - detection limit, in wt. \%): 

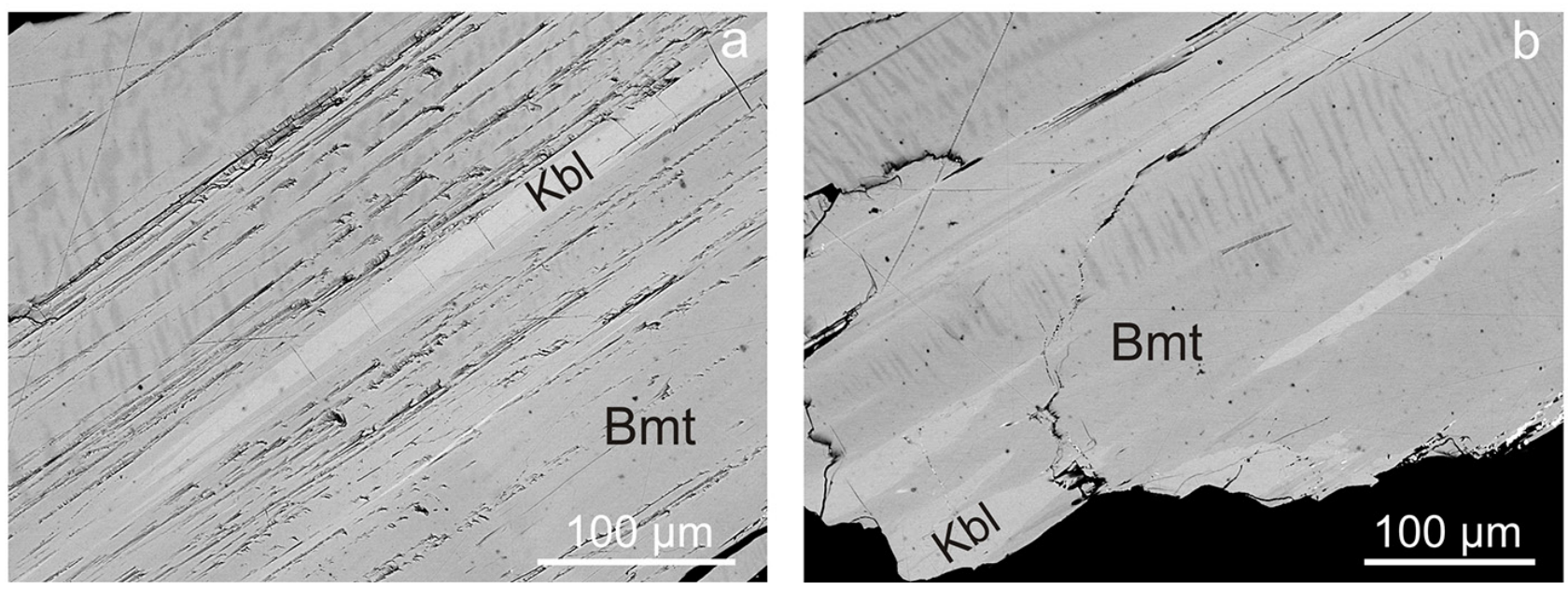

Fig. 2a - Bismuthinite (Bmt) associated with kobellite (Kbl). The darker ribbons in bismuthinite are phases fitting to the compositional gap between pekoite and gladite. Sample GPES2, BSE image. b - Exsolution lamellae and ribbons of phases fitting to the compositional gap between pekoite and gladite (dark grey) in bismuthinite (Bmt). Light grey elongated inclusions are kobellite (Kbl). Sample GPES2, BSE image.

$\operatorname{Ag}\left(\operatorname{Ag} L_{\alpha}\right.$ DL 0.07), $\mathrm{Bi}\left(\mathrm{Bi} M_{\beta} \mathrm{DL} 0.28\right), \mathrm{CdTe}\left(\mathrm{Cd} L_{\alpha} \mathrm{DL}\right.$ $0.07)$, chalcopyrite $\left(\mathrm{Cu} K_{\alpha}\right.$ DL $\left.0.05, \mathrm{~S}_{\alpha} \mathrm{DL} 0.05\right)$, halite $\left(\mathrm{Cl} K_{\alpha}\right.$ DL 0.04), $\mathrm{HgTe}\left(\mathrm{Hg} M_{\alpha}\right.$ DL 0.27), InAs (In $L_{\alpha}$ DL $0.05), \mathrm{Mn}\left(\mathrm{Mn} K_{\alpha} \mathrm{DL} 0.04\right)$, NiAs (As $L_{\alpha}$ DL 0.06), $\mathrm{PbS}$ $\left(\mathrm{Pb} M_{\alpha} \mathrm{DL} 0.11\right), \mathrm{PbSe}\left(\mathrm{Se} L_{\beta} \mathrm{DL} 0.08\right)$, pyrite $\left(\mathrm{Fe} K_{\alpha} \mathrm{DL}\right.$ $0.04), \mathrm{Sb}_{2} \mathrm{~S}_{3}\left(\mathrm{Sb} L_{\alpha} \mathrm{DL} 0.05\right), \mathrm{Sn}\left(\mathrm{Sn} L_{\alpha} \mathrm{DL} 0.05\right), \mathrm{PbTe}$ $\left(\mathrm{Te} L_{\alpha} \mathrm{DL} 0.06\right)$ and $\mathrm{ZnS}\left(\mathrm{Zn} K_{\alpha} \mathrm{DL}\right.$ 0.06). Contents of the above-listed elements, which are not included in the tables, were analyzed quantitatively but were consistently below the detection limit. Raw intensities were converted to the concentrations of elements using automatic "PAP" matrix-correction software (Pouchou and Pichoir 1985).

\section{Results and discussion}

\subsection{Bismuthinite-aikinite series}

Minerals of the bismuthinite-aikinite series, represented predominantly by bismuthinite are common, both in quartz veins hosted in porphyric granite as well as in P-enriched leucogranites. They form metallic lead grey to steel grey, prismatic to acicular crystals up to $1.5 \mathrm{~cm}$, or irregular aggregates up to $2 \times 2 \mathrm{~cm}$ in size enclosed in quartz. Bismuthinite is only very rarely directly associated with other sulfosalts (kobellite, Fig. 2a, 2b), but it is often accompanied by native bismuth, pyrite, fluorite,

Tab. 1 Representative chemical analyses of bismuthinite derivates from Gemerská Poloma (in wt. \%)

\begin{tabular}{|c|c|c|c|c|c|c|c|c|c|c|c|c|c|c|c|}
\hline \multirow{2}{*}{$\frac{\text { h.r. }}{\mathrm{Pb}}$} & \multicolumn{4}{|c|}{ GPES2 } & \multicolumn{2}{|c|}{$\begin{array}{c}\text { GPES3 } \\
\text { LG }\end{array}$} & \multicolumn{2}{|c|}{$\begin{array}{c}\text { GPES7 } \\
\text { PG }\end{array}$} & \multicolumn{2}{|c|}{$\begin{array}{c}\text { GPX1 } \\
\text { PG }\end{array}$} & \multicolumn{3}{|c|}{$\begin{array}{c}\text { GPA2 } \\
\text { PG }\end{array}$} & \multicolumn{2}{|c|}{$\begin{array}{c}\text { GPA8 } \\
\text { PG }\end{array}$} \\
\hline & 12.50 & 10.22 & 5.76 & 1.94 & 4.19 & 2.91 & 2.71 & 2.56 & 4.33 & 3.35 & 0.36 & 0.01 & 1.27 & 3.17 & 2.06 \\
\hline $\mathrm{u}$ & 3.60 & 2.89 & 1.79 & 0.33 & 1.22 & 0.83 & 0.73 & 0.74 & 1.36 & 1.00 & 0.24 & 0.28 & 0.37 & 0.83 & 0.51 \\
\hline b & 3.37 & 3.61 & 3.65 & & 3.55 & & 3.30 & 5.69 & 3.80 & & 14.35 & 24.99 & & 4.05 & 14.42 \\
\hline $\mathrm{Bi}$ & 62.17 & 64.22 & 69.79 & 73.47 & 71.83 & 67.47 & 74.40 & 71.69 & 70.88 & 72.20 & 63.84 & 52.20 & 52.31 & 60.73 & 61.78 \\
\hline & 18.62 & 18.85 & 18.82 & & 18.97 & 19.96 & 19.28 & 19.19 & 19.64 & 19.60 & 20.92 & 22.00 & 22.05 & 21.02 & 21.19 \\
\hline e & 18 & 0.18 & 0.22 & 020 & 0.22 & 0.00 & 0.32 & 0.26 & 0.15 & 0.10 & 0.00 & 0.00 & 0.00 & 0.00 & 0.00 \\
\hline $\mathrm{Cl}$ & 00 & 0.00 & 0.00 & 00 & 0.00 & 0.00 & 0.12 & 0.00 & 0.00 & 0.00 & 0.00 & 0.00 & 0.00 & 0.00 & 0.00 \\
\hline otal & 0.44 & 99.97 & 100.03 & 99.21 & 99.97 & 100.28 & 100.86 & 100.13 & 100.16 & 100.06 & 99.70 & 99.47 & 99.99 & 99.80 & 99.98 \\
\hline$\overline{\mathrm{Cu}}$ & 1.181 & 0.947 & 0.575 & 0.106 & 0.392 & 0.254 & 0.232 & 0.232 & 0.436 & 0.322 & 0.032 & 0.000 & 0.108 & 0.250 & 0.153 \\
\hline $\mathrm{Pb}$ & & 1.027 & & & & & & & 0.427 & & & & & 0.291 & 0.188 \\
\hline$\overline{\mathrm{Bi}}$ & 203 & 6.396 & 6.817 & 7. & 7.005 & 6.280 & 7.203 & 6.830 & 6.931 & 7. & 2.213 & & & 5.532 & 5.590 \\
\hline $\mathrm{Sb}$ & & 0.617 & & & 0.594 & & & & & & & & & .197 & 2.239 \\
\hline$\Sigma$ & 6.780 & 7.013 & 7.429 & 7.852 & 7.598 & 7.736 & 7.751 & 7.761 & 7.568 & 7.675 & 7.949 & 7.962 & 7.895 & 7.730 & 7.829 \\
\hline $\bar{S}$ & 12.108 & 12.236 & 11.980 & 12.051 & 12.053 & 12.110 & 12.165 & 11.917 & 12.519 & 12.448 & 12.252 & 12.007 & 12.137 & 12.481 & 12.495 \\
\hline $\mathrm{Se}$ & 0.048 & 0.047 & 0.057 & 0.051 & 0.056 & 0.000 & 0.082 & 0.065 & 0.038 & 0.025 & 0.000 & 0.000 & 0.000 & 0.000 & 0.000 \\
\hline$\Sigma$ & 12.156 & 12.283 & 12.037 & 12.103 & 12.109 & 12.110 & 12.247 & 11.982 & 12.557 & 12.473 & 12.252 & 12.007 & 12.137 & 12.481 & 12.495 \\
\hline $\mathrm{Cl}$ & 0.000 & 0.000 & 0.000 & 0.000 & 0.000 & 0.000 & 0.068 & 0.000 & 0.000 & 0.000 & 0.000 & 0.000 & 0.000 & 0.000 & 0.000 \\
\hline aik & 30.5 & 24.7 & 14.3 & 3.7 & 0.0 & 6.6 & 6.2 & 6.0 & 10.8 & 8.1 & 1.3 & 1.0 & 2.6 & 6.8 & 4.3 \\
\hline
\end{tabular}

calculated empirical formulae are based on $(\mathrm{Cu}+\mathrm{Pb}) / 2+(\mathrm{Sb}+\mathrm{Bi})=8$ apfu

h.r. - host rock; LG - leucogranite; $\mathrm{PG}$ - poprhyric granite 
fluorapatite, triplite, polycrase-(Y), Li-bearing micas or siderite.

Representative WDS analyses of minerals of the bismuthinite-aikinite series are given in Tab. 1 (all
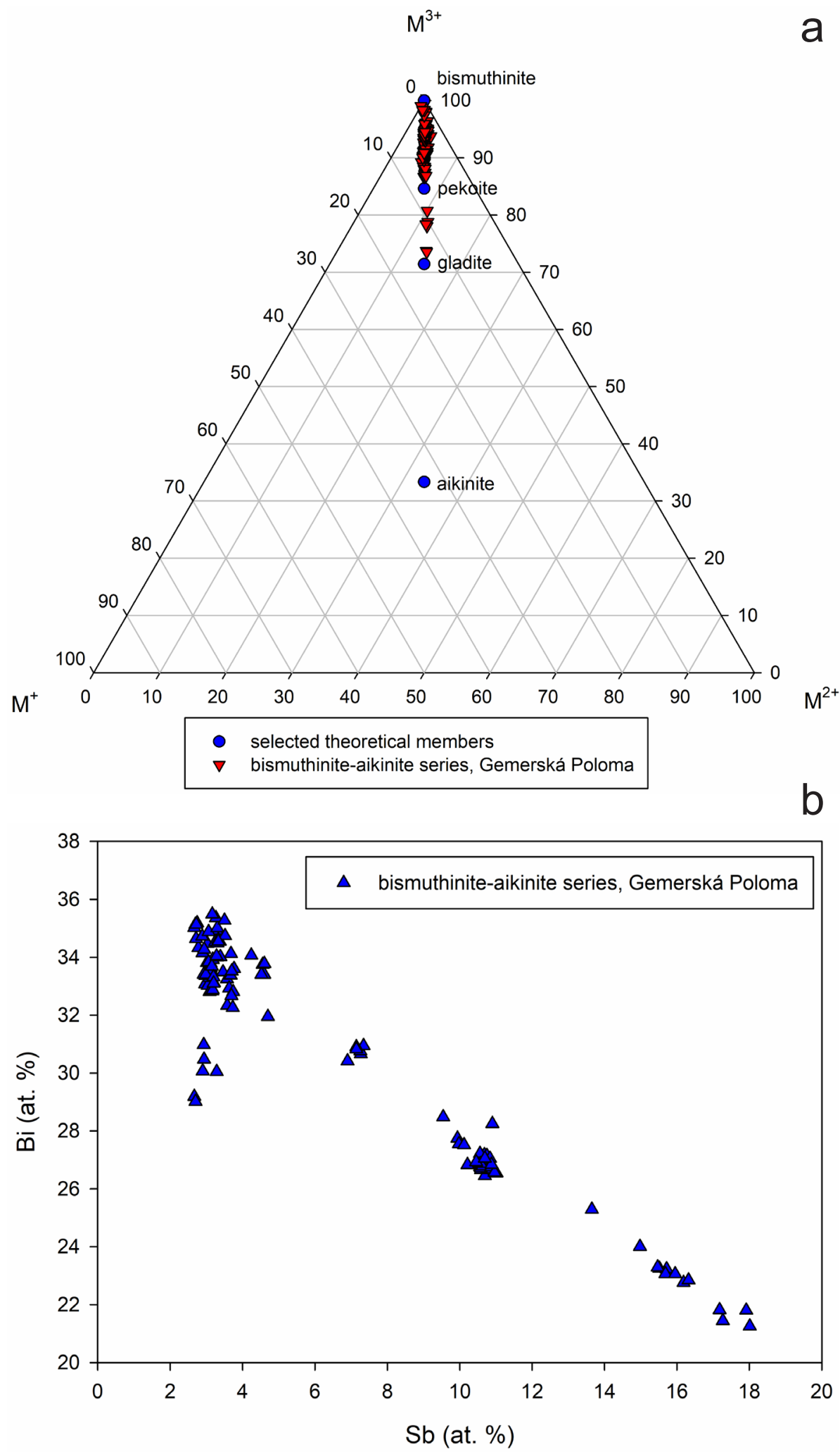

131 analyses and corresponding calculated empirical formulae are available in the supplementary data). Makovicky and Makovicky (1978) proposed to characterize members of the bismuthinite-aikinite series by $n_{\text {aik }}$, which corresponds to the percentage of $\mathrm{CuPbBiS}$ endmember in the $\mathrm{Bi}_{2} \mathrm{~S}_{3}-\mathrm{CuPbBiS}$ series. Based on this approach, the vast majority of samples from Gemerská Poloma correspond to bismuthinite (Fig. 3a), with the calculated value of $n_{\text {aik }}$ ranging between 1.0 to 14.3 (containing up to 0.58 apfu of $\mathrm{Cu}$ and 0.57 apfu of $\mathrm{Pb}$ ). In one sample, exsolved lamellae, and ribbons hosted in bismuthinite were observed (Fig. 2a, $2 \mathrm{~b})$. These phases with $n_{\text {aik }}$ ranging from 21.3 to 23.7 and 30.3 (Fig. 3a) are fitting to the compositional gap between pekoite (with $n_{\text {aik }}=16.7$ ) and gladite $\left(n_{\text {aik }}=33.3\right)$ and may represent new members of the bismuthinite-aikinite series. Similar exsolved phases with $n_{\text {aik }}=21-22$ and $n_{\text {aik }}=25-27$ were described by Topa et al. (2002) from Felbertal scheelite deposit (Austria), as well as by Cook (1997) from epithermal veins near Baia Borşa (Romania), Ciobanu and Cook (2000) and Cook and Ciobanu (2003) from Ocna de Fier skarn deposit (Romania), Xiang-Ping et al. (2001) from Funishan skarn deposit (China), Pršek and Mikuš (2006) from Kolba deposit near Lubietová (Slovakia) or Voudouris et al. (2013) from Stanos deposit in Chalkidiki (Greece). The amount of $\mathrm{Sb}$ substituting for Bi (Fig. 3b) varies in the studied samples considerably from 0.55 up to

Fig. 3a - The composition of minerals of the bismuthinite-aikinite series from Gemerská Poloma in ternary plot $M^{+}-M^{2+}-M^{\beta^{+}} . \mathbf{b}-$ Variation of $\mathrm{Sb}$ and Bi contents (at. \%) in minerals of the bismuthinite-aikinite series from $\mathrm{Ge}$ merská Poloma. 


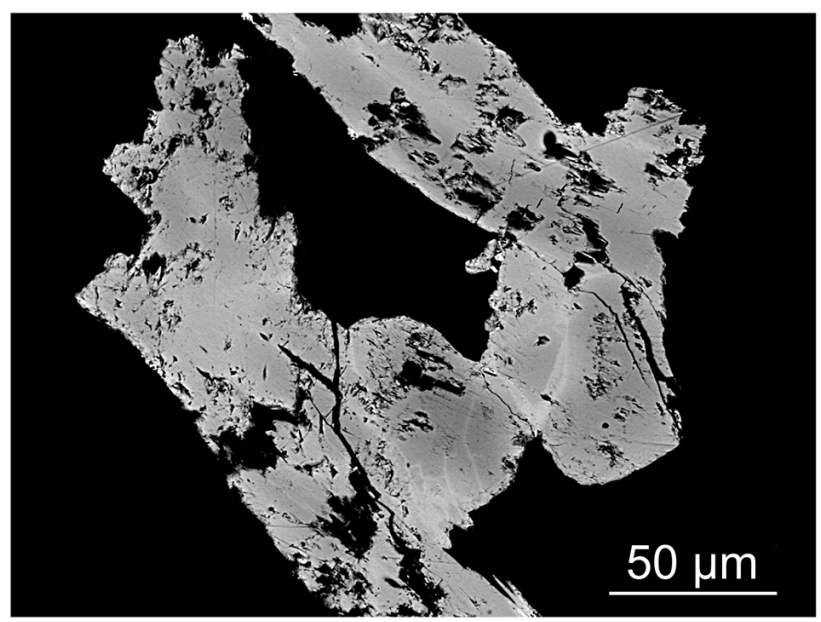

Fig. 4 Irregular chemical zoning of bismuthinite caused by variation of $\mathrm{Bi}$ and $\mathrm{Sb}$ contents. Sample GPA2, BSE image.

$3.63 a p f u$, locally causing weak, irregular chemical zoning (Fig. 4). The samples from quartz veins hosted in porphyric granite tend to be more $\mathrm{Sb}$ enriched than those from P-enriched leucogranite. Besides, minor concentrations of Se (up to $0.09 \mathrm{apfu}$ ) were also detected in some samples.
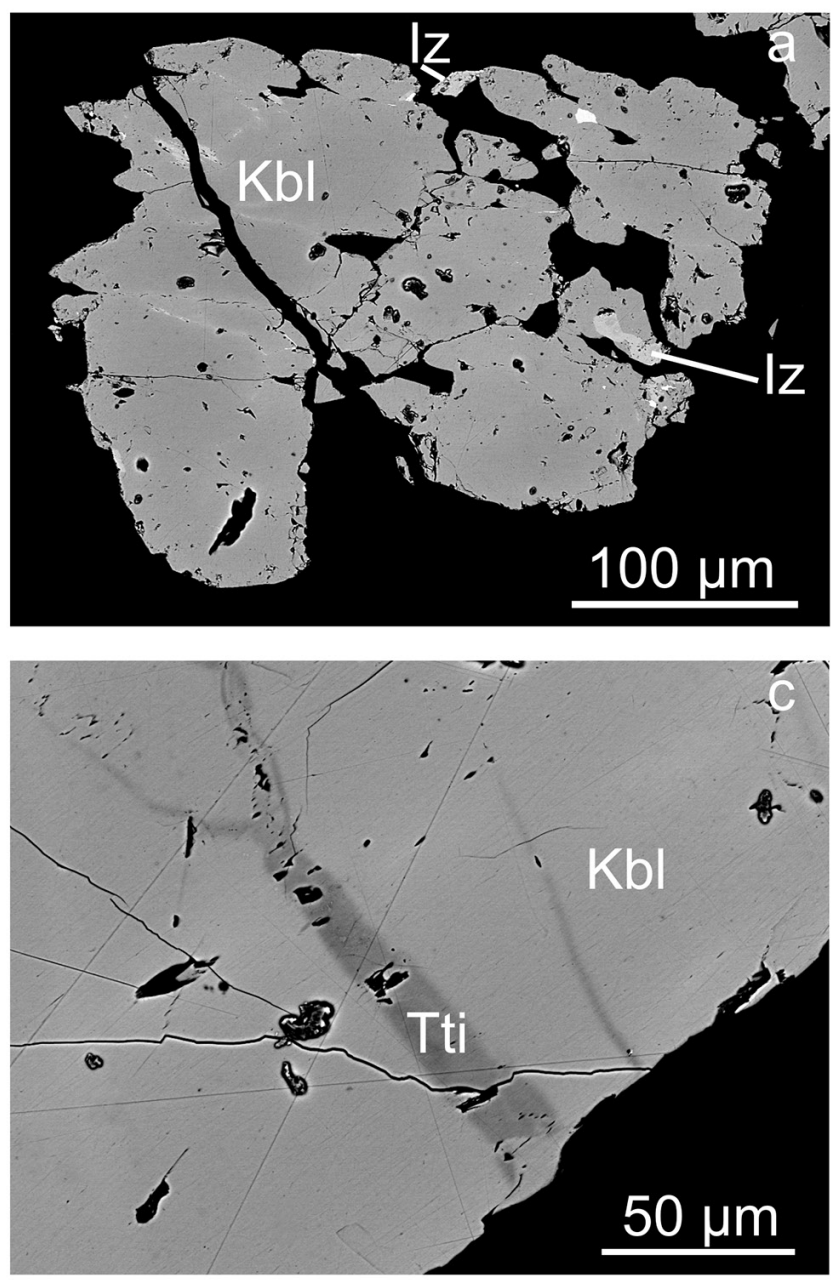

\subsection{Kobellite \\ homologous series}

\subsubsection{Kobellite-tintinaite series}

Minerals of the kobellite-tintinaite series are the most common sulfosalts and occur as individual acicular to prismatic crystals up to $1.5 \mathrm{~cm}$ or radial groups and irregular aggregates up to $3 \times 3 \mathrm{~cm}$ in size embedded in quartz. They occur both in porphyric as well as in P-enriched leucogranites and are associated with bismuthinite (Fig. 2a, 2b), minerals of the giessenite-izoklakeite series (Fig. 5a), tiny inclusions of native bismuth and locally also with jamesonite (Fig. 5b), galena or bournonite. Other minerals frequently associated with minerals of the kobellite-tintinaite series are pyrite, fluorite, fluorapatite, siderite and albite.

Representative chemical analyses of minerals of the kobellite-tintinaite series from Gemerská Poloma and the corresponding empirical formulae are shown in Tab. 2 (all 208 analyses and calculated empirical formulae are available in supplementary data). The calculated value of $N$ (order number of kobellite homolog, see Zakrzewski and Makovicky 1986 for details) ranges from 1.85 to

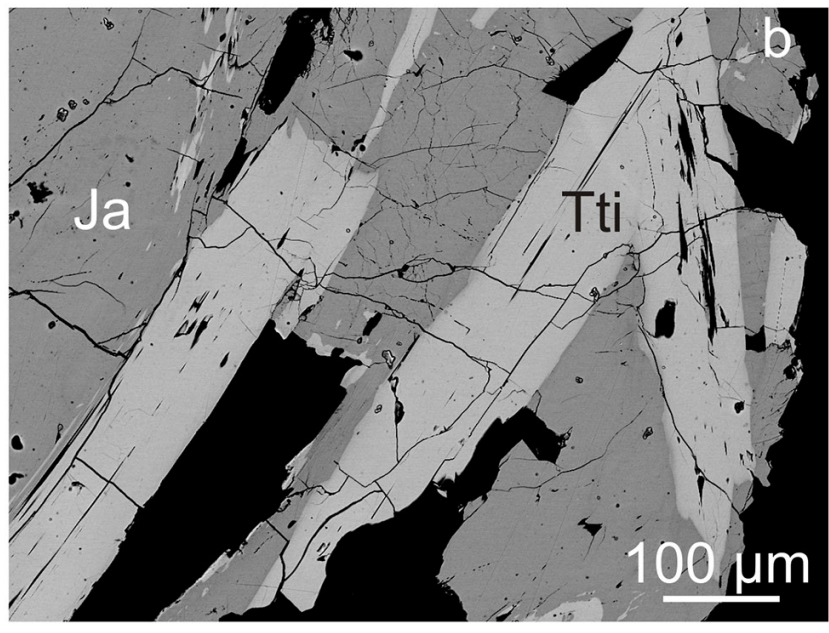

Fig. 5a - Kobellite (Kbl) associated with tiny inclusions of minerals of the giessenite-izoklakeite series (Iz) and galena (white). Sample GPES4, BSE image. $\mathbf{b}$ - Tintinaite (Tti) associated with jamesonite (Ja). Sample GPES5, BSE image. c - Irregular veinlets of tintinaite (Tti) developed in kobellite (Kbl). Sample GPES4, BSE image. 
Tab. 2 Representative chemical analyses of minerals of the kobellite-tintinaite series from Gemerská Poloma (in wt. \%)

\begin{tabular}{|c|c|c|c|c|c|c|c|c|c|c|c|c|c|c|c|}
\hline \multirow{3}{*}{ h.r. } & \multicolumn{2}{|c|}{ GPES1 } & \multicolumn{2}{|c|}{ GPES2 } & \multicolumn{2}{|c|}{ GPES4 } & \multicolumn{2}{|c|}{ GPES5 } & \multicolumn{2}{|c|}{ GPX2 } & \multicolumn{2}{|c|}{ GPA1 } & \multirow{3}{*}{$\begin{array}{c}\text { GPA2 } \\
\text { PG } \\
\text { Tti } \\
\end{array}$} & \multirow{3}{*}{$\begin{array}{c}\text { GPA5 } \\
\text { PG } \\
\text { Tti } \\
\end{array}$} & \multirow{3}{*}{$\begin{array}{c}\text { GPA7 } \\
\text { LG } \\
\text { Kbl } \\
\end{array}$} \\
\hline & \multirow{2}{*}{\multicolumn{2}{|c|}{$\begin{array}{l}\text { LG } \\
\mathrm{Kbl}\end{array}$}} & \multirow{2}{*}{\multicolumn{2}{|c|}{$\begin{array}{l}\text { LG } \\
\mathrm{Kbl}\end{array}$}} & \multicolumn{2}{|c|}{ LG } & \multirow{2}{*}{\multicolumn{2}{|c|}{$\begin{array}{l}\text { PG } \\
\text { Tti }\end{array}$}} & \multirow{2}{*}{\multicolumn{2}{|c|}{$\begin{array}{l}\text { PG } \\
\text { Tti }\end{array}$}} & \multirow{2}{*}{\multicolumn{2}{|c|}{$\begin{array}{l}\text { PG } \\
\text { Tti }\end{array}$}} & & & \\
\hline & & & & & $\mathrm{Kbl}$ & Tti & & & & & & & & & \\
\hline$\overline{\mathrm{Pb}}$ & 32.66 & 32.37 & 32.76 & 30.77 & 33.19 & 36.37 & 34.40 & 34.67 & 34.58 & 34.57 & 36.62 & 36.11 & 34.27 & 37.01 & 34.43 \\
\hline $\mathrm{Ag}$ & 0.26 & 0.29 & 0.22 & 0.00 & 0.22 & 0.00 & 0.19 & 0.13 & 0.13 & 0.00 & 0.12 & 0.16 & 0.48 & 0.00 & 0.00 \\
\hline $\mathrm{Cu}$ & 1.70 & 1.75 & 1.76 & 1.65 & 1.64 & 1.83 & 2.28 & 2.13 & 2.09 & 2.15 & 2.01 & 2.00 & 1.84 & 1.88 & 1.64 \\
\hline $\mathrm{Fe}$ & 0.26 & 0.29 & 0.20 & 0.00 & 0.29 & 0.31 & 0.00 & 0.00 & 0.00 & 0.05 & 0.18 & 0.21 & 0.26 & 0.27 & 0.26 \\
\hline $\mathrm{Zn}$ & 0.00 & 0.00 & 0.00 & 0.00 & 0.00 & 0.00 & 0.00 & 0.00 & 0.00 & 0.00 & 0.00 & 0.10 & 0.00 & 0.00 & 0.09 \\
\hline $\mathrm{Sb}$ & 7.85 & 8.82 & 9.37 & 4.64 & 9.31 & 17.88 & 22.40 & 24.18 & 20.27 & 22.92 & 23.45 & 23.58 & 18.97 & 21.70 & 11.09 \\
\hline $\mathrm{Bi}$ & 38.84 & 38.44 & 37.43 & 44.95 & 37.04 & 24.86 & 20.61 & 19.50 & 23.24 & 20.24 & 17.89 & 17.60 & 24.81 & 19.56 & 34.30 \\
\hline 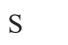 & 18.21 & 18.29 & 17.61 & 17.15 & 18.21 & 19.21 & 19.79 & 19.24 & 19.99 & 20.18 & 19.92 & 19.72 & 19.48 & 19.71 & 18.55 \\
\hline $\mathrm{Se}$ & 0.00 & 0.00 & 0.20 & 0.32 & 0.00 & 0.00 & 0.00 & 0.00 & 0.00 & 0.00 & 0.00 & 0.00 & 0.00 & 0.00 & 0.00 \\
\hline $\mathrm{Cl}$ & 0.00 & 0.07 & 0.00 & & & & 0.00 & & & & & & 00 & 00 & 0.00 \\
\hline total & 99.78 & 100.32 & 99.55 & 99.53 & 99.99 & 100.57 & 99.67 & 99.85 & 100.30 & 100.10 & 100.25 & 99.48 & 100.11 & 100.13 & 100.36 \\
\hline$\overline{\mathrm{Pb}}$ & 9.835 & 9.646 & 9.969 & 9.665 & 9.919 & & 9.479 & 9.637 & & 9.419 & 9.997 & 9.933 & 9.598 & 10.234 & 10.147 \\
\hline $\mathrm{Ag}$ & 0.150 & 0.166 & 0.129 & 0.000 & 0.126 & 0.000 & 0.101 & 0.070 & 0.068 & 0.000 & 0.063 & 0.085 & 0.256 & 0.000 & 0.000 \\
\hline$\Sigma$ & 9.986 & 9.812 & 10.097 & 9.665 & 10.046 & 10.260 & 9.580 & 9.707 & 9.607 & 9.419 & 10.060 & 10.017 & 9.855 & 10.234 & 10.147 \\
\hline$\overline{\mathrm{Cu}}$ & 1.669 & 1.700 & 1.746 & 1.690 & 1.598 & 1.683 & 2.049 & 1.930 & 1.881 & 1.910 & 1.789 & 1.794 & 1.684 & 1.694 & 1.576 \\
\hline $\mathrm{Fe}$ & 0.291 & 0.321 & 0.226 & 0.000 & 0.322 & 0.324 & 0.000 & 0.000 & 0.000 & 0.050 & 0.182 & 0.214 & 0.274 & 0.280 & 0.284 \\
\hline $\mathrm{Zn}$ & 0.000 & 0.000 & 0.000 & 0.000 & 0.000 & 0.000 & 0.000 & 0.000 & 0.000 & 0.000 & 0.000 & 0.087 & 0.000 & 0.000 & 0.08 \\
\hline $\bar{\Sigma}$ & 1.960 & 2.021 & 1.972 & 1.690 & 1.920 & 2.008 & 2.049 & 1.930 & 1.881 & 1.960 & 1.971 & 2.095 & 1.957 & 1.974 & 1.94 \\
\hline $\mathrm{Sb}$ & 4.023 & 4.472 & 4.852 & 2.480 & 4.735 & 8.583 & 10.504 & 11.439 & 9.515 & 10.627 & 10.893 & 11.037 & 9.043 & 10.215 & 5.562 \\
\hline $\mathrm{Bi}$ & 11.597 & 11.357 & 11.293 & 13.999 & 10.976 & 6.953 & 5.631 & 5.374 & 6.359 & 5.467 & 4.842 & 4.800 & 6.889 & 5.364 & 10.022 \\
\hline$\Sigma$ & 15.620 & 15.829 & 16.145 & 16.480 & 15.711 & 15.536 & 16.135 & 16.813 & 15.874 & 16.095 & 15.736 & 15.837 & 15.933 & 15.579 & 15.584 \\
\hline $\bar{S}$ & 35.435 & 35.216 & 34.626 & 34.810 & 35.167 & 35.015 & 35.237 & 34.550 & 35.638 & 35.527 & 35.138 & 35.050 & 35.255 & 35.213 & 35.325 \\
\hline $\mathrm{Se}$ & 0.000 & 0.000 & 0.160 & 0.264 & 0.000 & 0.000 & 0.000 & 0.000 & 0.000 & 0.000 & 0.000 & & 0.000 & 0.000 & 0.000 \\
\hline$\Sigma$ & 35.435 & 35.216 & 34.786 & 35.073 & 35.167 & 35.015 & 35.237 & 34.550 & 35.638 & 35.527 & 35.138 & 35.050 & 35.255 & 35.213 & 35.325 \\
\hline $\mathrm{Cl}$ & 0.000 & 0.122 & 0.000 & 0.092 & 0.157 & 0.181 & 0.000 & 0.000 & 0.000 & 0.000 & 0.096 & 0.000 & 0.000 & 0.000 & 0.000 \\
\hline $\mathrm{N}$ & 2.00 & 1.95 & 1.98 & 1.91 & 1.98 & 2.00 & 1.95 & 1.90 & 1.97 & 1.89 & 2.00 & 2.00 & 1.98 & 2.01 & 2.00 \\
\hline
\end{tabular}

calculated empirical formulae are based on sum of all atoms $=63 \mathrm{apfu}$

h.r. - host rock; LG - leucogranite; PG - poprhyric granite

2.06. $\mathrm{The} \mathrm{Sb} /(\mathrm{Sb}+\mathrm{Bi})$ atomic ratio in samples from $\mathrm{Ge}-$ merská Poloma (Fig. 6) varies considerably between 0.13

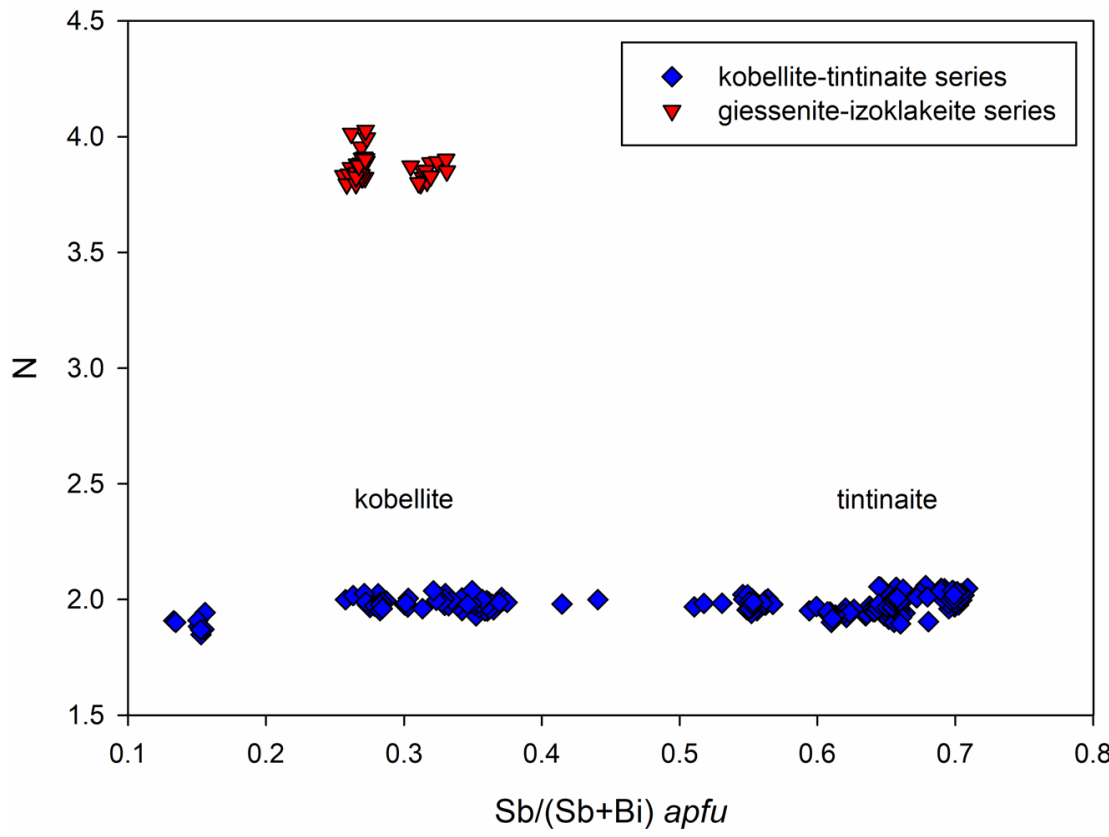

and 0.71 , representing a rather wide compositional range between kobellite and tintinaite. However, in individual samples, the $\mathrm{Sb}$ versus $\mathrm{Bi}$ variation tends to be relatively small and only weak chemical zoning was rarely observed in one case (Fig. 5c, sample GPES4). In general, samples from the quartz veins hosted in porphyric granite tend to be $\mathrm{Sb}$-dominant (tintinaite), whereas Bi-dominant compositions (kobellite) prevail in quartz veins hosted in P-enriched leucogranite. All studied samples contain significant concentrations of $\mathrm{Cu}$ (1.44 up to 2.05 apfu), but variable amounts of $\mathrm{Fe}$ (0.00 up to 0.61 apfu). Variation of $\mathrm{Cu}$ and $\mathrm{Fe}$ contents in minerals of the kobellite-tintinaite series from Gemerská Poloma is shown in Fig. 7a. The overall $\mathrm{Cu}+\mathrm{Fe}$ content ranges from

Fig. 6 Variation of $\mathrm{Sb} /(\mathrm{Sb}+\mathrm{Bi})$ ratio and calculated value of $\mathrm{N}$ for minerals of the kobellite homologous series from Gemerská Poloma. 
1.65 to $2.10 \mathrm{apfu}$, with an average of $1.95 \mathrm{apfu}$, close to the ideal value of 2 apfu (e.g., Zakrzewski and Makovicky 1986; Moëlo et al. 1995; Wagner and Johnsson 2001; Pršek et al. 2008; Mikuš et al. 2018). The maximum content of $\mathrm{Ag}$ substituting for $\mathrm{Pb}$ (Fig. 7b) is 0.26 apfu. In addition, minor amounts of $\mathrm{Zn}$ (up to $0.09 \mathrm{apfu}$ ), Se (up to 0.26 $a p f u$ ) and $\mathrm{Cl}$ (up to $0.40 a p f u$ ) were also locally detected.

\subsubsection{Giessenite-izoklakeite series}

Minerals of the giessenite-izoklakeite series are rare and were identified only in two samples, both from the quartz veins hosted in P-enriched leucogranite. They form subhedral grains and aggregates reaching up to $100 \mu \mathrm{m}$ in size intimately intergrown with kobellite (Fig. 5a, 8). Representative chemical analyses of minerals of the giessenite-izoklakeite series from $\mathrm{Ge}-$ merská Poloma and the corresponding empirical formulae are given in Tab. 3 (all 45 analyses and calculated empirical formulae are available in supplementary data). The calculated values of $N$ range from 3.80 to 4.03 . The values of $\mathrm{Sb} /(\mathrm{Sb}+\mathrm{Bi})$ ratio in studied samples vary from 0.26 to 0.33 (Fig. 6) and slightly differ between the two studied samples $(0.26$ to 0.27 in sample GPES4 and 0.31 to 0.33 in sample GPA7).

There is only a quasi-continuous solid solution between giessenite and izoklakeite with increasing $\mathrm{Sb} / \mathrm{Bi}$ ratio (Moëlo et al. 2008) since, according to the published data, the symmetry of giessenite is monoclinic (Graser and Harris 1986; Makovicky and KarupMøller 1986) and that of Bi-rich izoklakeite is orthorhombic (Harris et al. 1986; Makovicky and Mumme 1986; Armbruster and Hummel 1987). The exact $\mathrm{Sb} / \mathrm{Bi}$ ratio at which the symmetry changes is unknown, but according to Moëlo et al. (1995, 2008), the name izoklakeite is applied to all phases with $\mathrm{Sb} / \mathrm{Bi}$ atomic ratio close to 1 (i.e., $\mathrm{Sb} /(\mathrm{Sb}+\mathrm{Bi}$ ) close to 0.50 ), even for samples with $\mathrm{Bi}>\mathrm{Sb}$. Pažout

Fig. 7a- Cu vs. Fe (apfu) plot for members of the kobellite homologous series from $\mathrm{Ge}-$ merská Poloma. $\mathbf{b}-\mathrm{Ag} v s . \mathrm{Pb}($ apfu) plot for members of the kobellite homologous series from Gemerská Poloma. et al. (2017) estimated that the symmetry change between giessenite and izoklakeite takes place somewhere in the range of $\mathrm{Sb} /(\mathrm{Sb}+\mathrm{Bi})$ values of 0.20 to 0.30 . Ozawa et al. (1998) described so far the most Bi-enriched izoklakeite from Otome mine in Japan with $\mathrm{Sb} /(\mathrm{Sb}+\mathrm{Bi})$ ratio ranging from 0.31 to 0.33 . Thus, it is possible that both giessenite and Bi-rich izoklakeite are present at Gemerská Poloma, but all attempts to extract suitable single-crystals to confirm this hypothesis by single-crystal XRD were unsuccessful. Both studied samples of minerals of the giessenite-izoklakeite series contain substantial amounts of $\mathrm{Cu}$ (1.81 to 2.15 apfu), but surprisingly no Fe (Fig. 7a). Furthermore, the
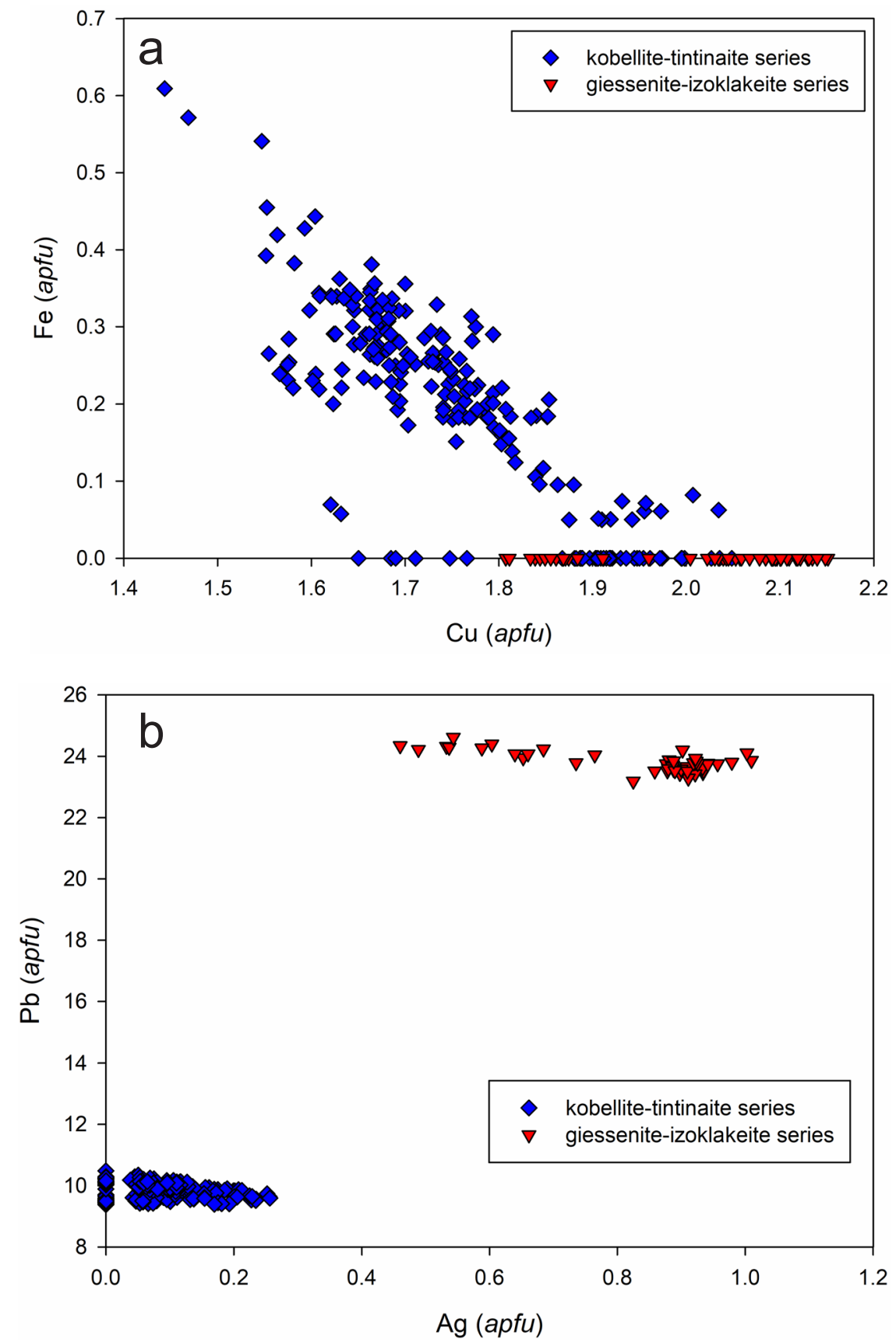


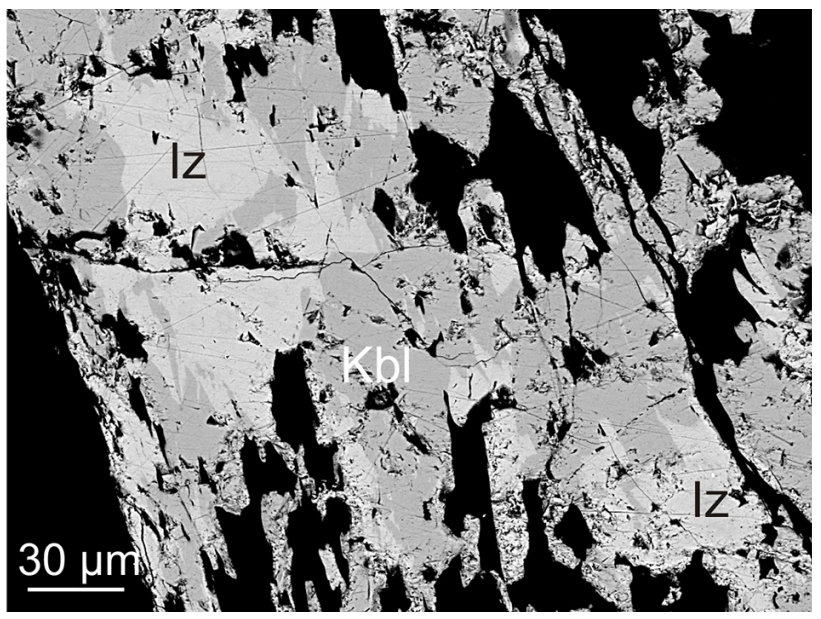

Fig. 8 Minerals of the giessenite-izoklakeite series (Iz) intergrown with kobellite (Kbl). Sample GPA7, BSE image. presence of $\mathrm{Ag}$ (ranging from 0.46 to $1.01 \mathrm{apfu}$ ) substituting for $\mathrm{Pb}$ (Fig. 7b) according to lillianite type substitution $\mathrm{Ag}+\mathrm{Bi}=2 \mathrm{~Pb}$ is typical.

\subsection{Pb-Sb sulfosalts}

$\mathrm{Pb}-\mathrm{Sb}$ sulfosalts, especially jamesonite and robinsonite, as well as minor amounts of boulangerite are common minerals in quartz veins hosted in porphyric granite, but they are absent in hydrothermal quartz veins hosted in P-enriched leucogranite.

\subsubsection{Boulangerite}

Boulangerite is infrequent. It occurs as acicular crystals up to $7 \mathrm{~mm}$ long, developed together with jamesonite in

Tab. 3 Representative chemical analyses of minerals of the giessenite-izoklakeite series from Gemerská Poloma (in wt. \%)

\begin{tabular}{|c|c|c|c|c|c|c|c|c|c|c|c|c|c|c|c|}
\hline \multirow[b]{2}{*}{$\mathrm{Pb}$} & \multicolumn{7}{|c|}{ GPES4 } & \multicolumn{8}{|c|}{ GPA7 } \\
\hline & 45.11 & 44.76 & 44.42 & 44.31 & 44.94 & 44.82 & 45.86 & 46.51 & 46.65 & 46.76 & 46.23 & 46.59 & 47.01 & 46.27 & 45.98 \\
\hline $\mathrm{Ag}$ & 0.93 & 0.86 & 0.91 & 0.82 & 0.99 & 0.85 & 0.89 & 0.53 & 0.49 & 0.46 & 0.66 & 0.60 & 0.54 & 0.64 & 0.74 \\
\hline $\mathrm{Cu}$ & 1.19 & 1.19 & 1.14 & 1.19 & 1.23 & 1.26 & 1.24 & 1.06 & 1.07 & 1.11 & 1.08 & 1.08 & 1.09 & 1.09 & 1.10 \\
\hline $\mathrm{Sb}$ & 6.43 & 6.02 & 6.10 & 6.04 & 6.33 & 6.25 & 6.08 & 7.34 & 7.33 & 7.41 & 7.38 & 7.13 & 7.45 & 7.41 & 7.58 \\
\hline $\mathrm{Bi}$ & 29.40 & 30.00 & 29.79 & 29.72 & 28.92 & 29.67 & 29.41 & 27.56 & 27.72 & 27.43 & 28.12 & 27.90 & 27.27 & 27.54 & 27.72 \\
\hline S & 16.97 & 16.65 & 16.92 & 17.20 & 16.63 & 16.89 & 16.69 & 17.02 & 17.21 & 17.12 & 17.05 & 16.94 & 16.90 & 17.15 & 17.27 \\
\hline total & 100.03 & 99.48 & 99.28 & 99.27 & 99.04 & 99.80 & 100.17 & 100.02 & 100.47 & 100.29 & 100.52 & 100.24 & 100.26 & 100.10 & 100.39 \\
\hline $\mathrm{Pb}$ & 23.623 & 23.752 & 23.422 & 23.188 & 23.861 & 23.516 & 24.200 & 24.323 & 24.220 & 24.343 & 24.075 & 24.396 & 24.616 & 24.077 & 23.787 \\
\hline $\mathrm{Ag}$ & 0.933 & 0.877 & 0.922 & 0.825 & 1.010 & 0.858 & 0.902 & 0.532 & 0.489 & 0.460 & 0.660 & 0.603 & 0.543 & 0.640 & 0.735 \\
\hline$\Sigma$ & 24.556 & 24.629 & 24.344 & 24.013 & 24.871 & 24.375 & 25.101 & 24.856 & 24.708 & 24.803 & 24.735 & 25.000 & 25.160 & 24.716 & 24.522 \\
\hline $\mathrm{Cu}$ & 2.039 & 2.059 & 1.960 & 2.022 & 2.129 & 2.151 & 2.140 & 1.808 & 1.811 & 1.884 & 1.834 & 1.844 & 1.861 & 1.849 & 1.856 \\
\hline $\mathrm{Sb}$ & 5.726 & 5.436 & 5.473 & 5.377 & 5.719 & 5.577 & 5.456 & 6.532 & 6.476 & 6.565 & 6.540 & 6.353 & 6.639 & 6.561 & 6.673 \\
\hline $\mathrm{Bi}$ & 15.262 & 15.784 & 15.574 & 15.422 & 15.225 & 15.435 & 15.387 & 14.290 & 14.269 & 14.158 & 14.519 & 14.485 & 14.158 & 14.208 & 14.218 \\
\hline $\mathrm{S}$ & 57.416 & 57.092 & 57.649 & 58.166 & 57.056 & 57.275 & 56.915 & 57.515 & 57.735 & 57.590 & 57.373 & 57.318 & 57.183 & 57.664 & 57.731 \\
\hline $\mathrm{Cl}$ & 0.000 & 0.000 & 0.000 & 0.000 & 0.000 & 0.187 & 0.000 & 0.000 & 0.000 & 0.000 & 0.000 & 0.000 & 0.000 & 0.000 & 0.000 \\
\hline $\mathrm{N}$ & 3.89 & 3.83 & 3.84 & 3.80 & 3.99 & 3.83 & 4.01 & 3.82 & 3.80 & 3.81 & 3.80 & 3.87 & 3.89 & 3.85 & 3.83 \\
\hline
\end{tabular}

calculated empirical formulae are based on sum of all atoms $=105 \mathrm{apfu}$
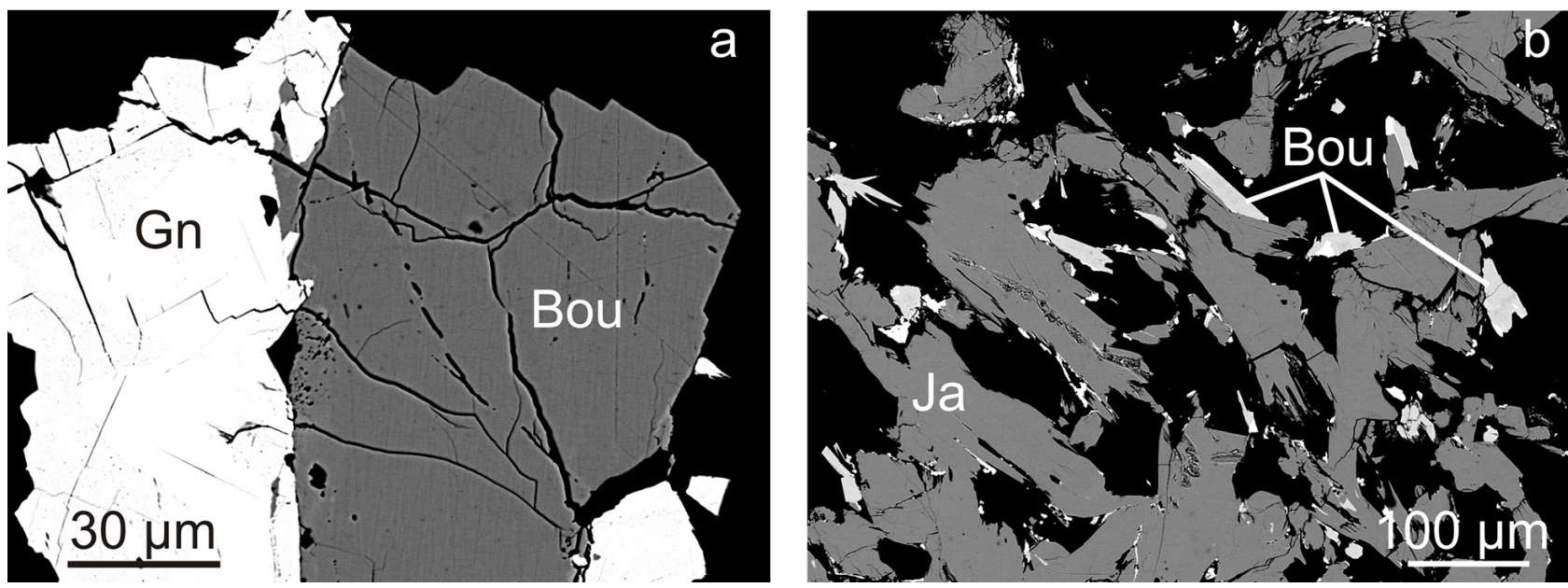

Fig. 9a - Boulangerite (Bou) in contact with galena (Gn). Sample GPN4, BSE image. b - Boulangerite (Bou) associated with jamesonite (Ja) and galena (white). Sample GPN7, BSE image. 
Sulfosalts from the Elisabeth mine, Gemerská Poloma, Slovakia

Tab. 4 Representative chemical analyses of boulangerite from Gemerská Poloma (in wt. \%)

\begin{tabular}{|c|c|c|c|c|c|c|c|c|c|c|c|c|c|c|c|}
\hline \multirow[b]{2}{*}{$\mathrm{Pb}$} & \multicolumn{2}{|c|}{ GPX3 } & \multicolumn{3}{|c|}{ GPN1 } & \multicolumn{2}{|c|}{ GPN2 } & \multicolumn{3}{|c|}{ GPN3 } & \multicolumn{2}{|c|}{ GPN5 } & \multicolumn{3}{|c|}{ GPN6 } \\
\hline & 38.59 & 38.33 & 39.68 & 39.98 & 38.93 & 39.71 & 39.88 & 37.53 & 39.54 & 38.36 & 40.52 & 40.35 & 41.28 & 41.40 & 40.56 \\
\hline $\mathrm{Cu}$ & 0.00 & 0.00 & 0.00 & 0.00 & 0.00 & 0.00 & 0.00 & 0.00 & 0.07 & 0.00 & 0.00 & 0.10 & 0.00 & 0.00 & 0.00 \\
\hline $\mathrm{Fe}$ & 0.00 & 0.00 & 0.00 & 0.00 & 0.00 & 0.00 & 0.00 & 0.00 & 0.00 & 0.00 & 0.00 & 0.00 & 0.00 & 0.11 & 0.00 \\
\hline $\mathrm{Sb}$ & 25.37 & 25.31 & 30.22 & 31.27 & 28.48 & 30.81 & 31.83 & 22.14 & 30.05 & 25.98 & 33.43 & 32.39 & 36.75 & 35.56 & 34.36 \\
\hline $\mathrm{Bi}$ & 15.90 & 16.05 & 9.48 & 8.45 & 12.66 & 9.29 & 7.77 & 20.33 & 10.68 & 15.30 & 5.88 & 6.77 & 1.34 & 3.00 & 4.27 \\
\hline $\mathrm{S}$ & 20.12 & 20.11 & 20.70 & 20.99 & 20.81 & 20.96 & 20.63 & 19.72 & 20.30 & 19.92 & 20.24 & 20.47 & 20.46 & 20.13 & 20.47 \\
\hline $\mathrm{Cl}$ & 0.00 & 0.00 & 0.05 & 0.00 & 0.00 & 0.00 & 0.00 & 0.00 & 0.00 & 0.07 & 0.00 & 0.00 & 0.00 & 0.00 & 0.00 \\
\hline total & 99.98 & 99.79 & 100.13 & 100.69 & 100.88 & 100.77 & 100.12 & 99.72 & 100.64 & 99.63 & 100.07 & 100.09 & 99.83 & 100.20 & 99.66 \\
\hline $\mathrm{Pb}$ & 3.901 & 3.879 & 3.892 & 3.877 & 3.820 & 3.857 & 3.902 & 3.874 & 3.909 & 3.889 & 3.982 & 3.953 & 4.000 & 4.046 & 3.961 \\
\hline $\mathrm{Cu}$ & 0.000 & 0.000 & 0.000 & 0.000 & 0.000 & 0.000 & 0.000 & 0.000 & 0.023 & 0.000 & 0.000 & 0.031 & 0.000 & 0.000 & 0.000 \\
\hline $\mathrm{Fe}$ & 0.000 & 0.000 & 0.000 & 0.000 & 0.000 & 0.000 & 0.000 & 0.000 & 0.000 & 0.000 & 0.000 & 0.000 & 0.000 & 0.040 & 0.000 \\
\hline$\Sigma$ & 3.901 & 3.879 & 3.892 & 3.877 & 3.820 & 3.857 & 3.902 & 3.874 & 3.931 & 3.889 & 3.982 & 3.984 & 4.000 & 4.085 & 3.961 \\
\hline $\mathrm{Sb}$ & 4.364 & 4.359 & 5.042 & 5.160 & 4.755 & 5.093 & 5.300 & 3.890 & 5.055 & 4.482 & 5.591 & 5.400 & 6.060 & 5.913 & 5.710 \\
\hline $\mathrm{Bi}$ & 1.594 & 1.611 & 0.922 & 0.812 & 1.232 & 0.895 & 0.754 & 2.081 & 1.047 & 1.538 & 0.573 & 0.657 & 0.129 & 0.291 & 0.413 \\
\hline$\Sigma$ & 5.958 & 5.970 & 5.964 & 5.972 & 5.987 & 5.987 & 6.054 & 5.971 & 6.102 & 6.020 & 6.164 & 6.057 & 6.189 & 6.204 & 6.123 \\
\hline $\mathrm{S}$ & 13.141 & 13.151 & 13.116 & 13.151 & 13.194 & 13.155 & 13.043 & 13.155 & 12.967 & 13.049 & 12.854 & 12.958 & 12.811 & 12.711 & 12.916 \\
\hline $\mathrm{Cl}$ & 0.000 & 0.000 & 0.028 & 0.000 & 0.000 & 0.000 & 0.000 & 0.000 & 0.000 & 0.041 & 0.000 & 0.000 & 0.000 & 0.000 & 0.000 \\
\hline
\end{tabular}

are based on sum of all atoms $=23 \mathrm{apfu}$

cavities of quartz, subhedral to anhedral grains and aggregates replacing galena (Fig. 9a, GPN4) or individual subhedral crystals up to $100 \mu \mathrm{m}$ in size associated with jamesonite (Fig. 9b, GPN7). Other accompanying minerals are sphalerite, pyrite, fluorite, siderite, dolomite and albite. Representative chemical analyses of boulangerite are shown in Tab. 4 (all 61 analyses and calculated empirical formulae are available in supplementary data). Elevated contents of Bi (up to 0.32 apfu) substituting for $\mathrm{Sb}$ are typical (Fig. 10). Minor amounts of other elements such as $\mathrm{Fe}, \mathrm{As}$ or $\mathrm{Cl}$ (all reaching up to $0.04 \mathrm{apfu}$ ) were also detected.

\subsubsection{Robinsonite}

Robinsonite is a common sulfosalt in quartz veins hosted in porphyric granite. It forms irregular or radial aggregates up to $3 \times 3 \mathrm{~cm}$ in size, consisting of individual acicular crystals up to $1.5 \mathrm{~cm}$ long. Groups and aggregates of acicular crystals of robinsonite included in fluorite were also observed. Robinsonite is frequently associated mainly with jamesonite (Fig. 11), galena or sphalerite.

Quantitative chemical analyses and the corresponding calculated empirical formulae of

Fig. 10 Variation of $\mathrm{Sb}$ and $\mathrm{Bi}$ contents (at. \%) in $\mathrm{Pb}-\mathrm{Sb}$ sulfosalts and bournonite from Gemerská Poloma. robinsonite from Gemerská Poloma are given in Tab. 5 (all 107 analyses and calculated empirical formulae are available in supplementary data). Significant incorporation of $\mathrm{Bi}$ (ranging from 0.13 up to $2.08 \mathrm{apfu}$ ) is characteristic for robinsonite from Gemerská Poloma (Fig. 10). Similar elevated contents of $\mathrm{Bi}$ in robinsonite were so far described only by Jambor and Lachance (1968) from the Dodger tungsten mine in British Columbia (Canada), or by Števko and Sejkora (2017) from Č́žžko baňa occurrence near Ochtiná (Slovakia). Furthermore, minor concentrations of $\mathrm{Fe}$ (up to $0.07 \mathrm{apfu}$ ), $\mathrm{Cu}$ (up to $0.03 \mathrm{apfu}$ ) as well as $\mathrm{Cl}$ (up to $0.04 a p f u$ ) are present in robinsonite.

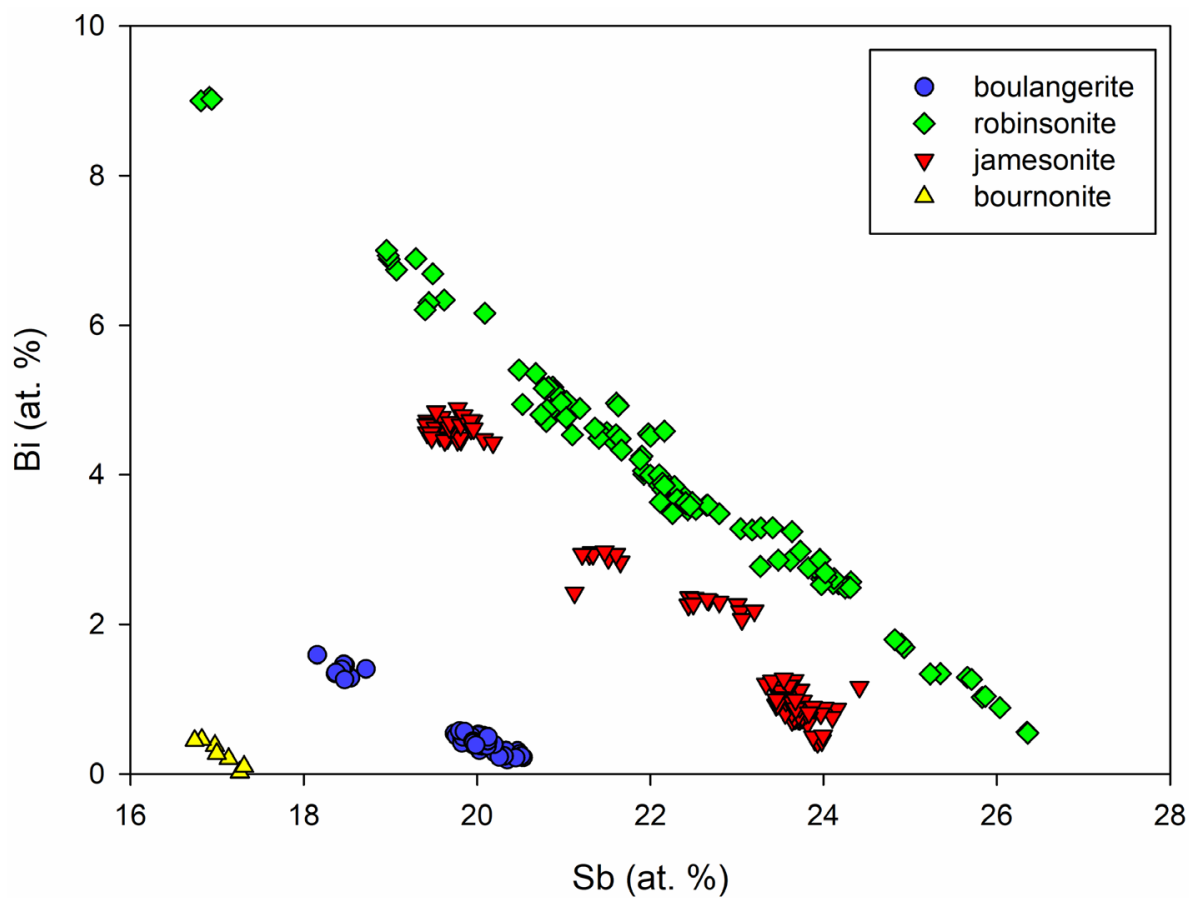




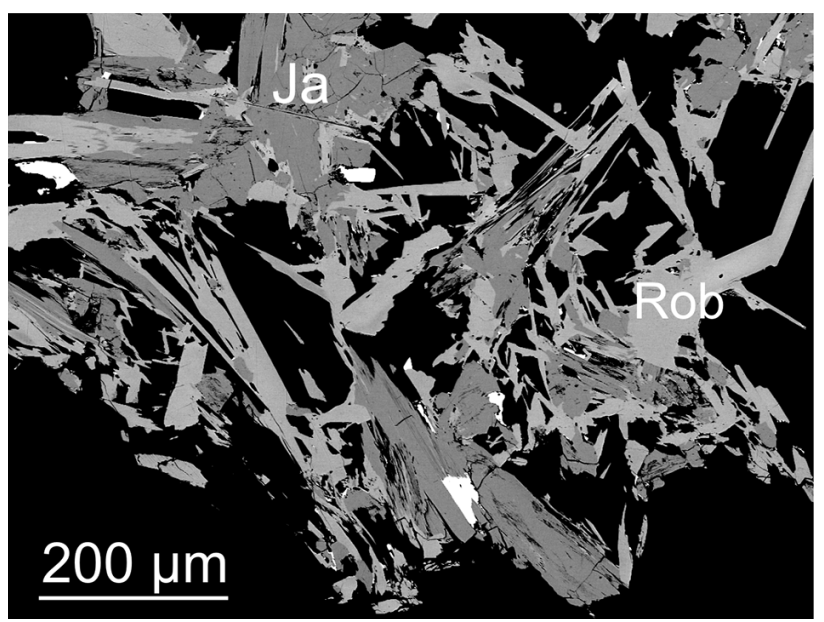

Fig. 11 Crystals of robinsonite (Rob) associated with jamesonite (Ja) and galena (white). Sample GPN5, BSE image.

\subsubsection{Jamesonite}

Jamesonite is an abundant mineral and it occurs as radial or irregular aggregates up to $3 \mathrm{~cm}$ embedded in quartz, which consists of individual acicular crystals up to $1 \mathrm{~cm}$ long. It is predominantly associated with other $\mathrm{Pb}-\mathrm{Sb}$ sulfosalts (robinsonite, boulangerite; Fig. 9b, 11) as well as sphalerite, galena, pyrite, arsenopyrite, fluorite, siderite and dolomite. In two cases, minerals of the kobellitetintinaite series (tintinaite; Fig. 12) were also found in direct association with jamesonite.

Representative chemical analyses of jamesonite from Gemerská Poloma and the corresponding empirical formulae are given in Tab. 6 (all 128 analyses and calculated empirical formulae are available in supplementary data). Jamesonite is characterized especially by an elevated content of Bi (ranging from 0.11 up to 1.22 apfu) substi-

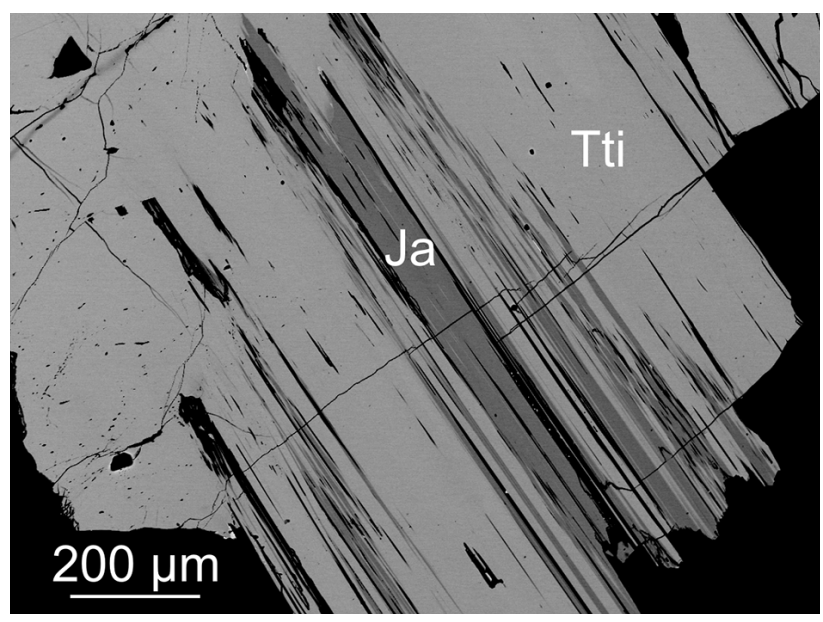

Fig. 12 Crystals of jamesonite (Ja) enclosed in tintinaite (Tti). Sample GPX2, BSE image.

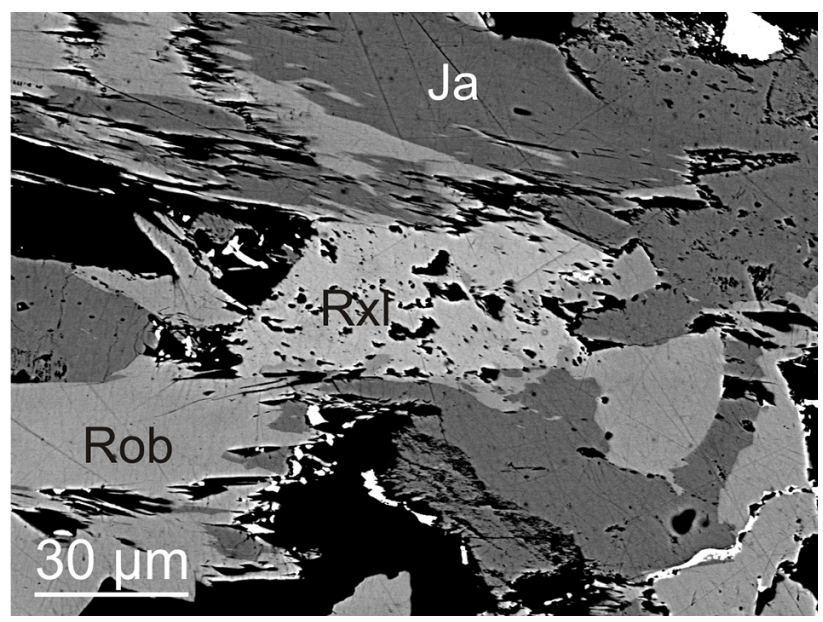

Fig. 13 Rouxelite (Rxl) associated with robinsonite (Rob), jamesonite (Ja) and galena (white). Sample GPN5, BSE image.

Tab. 5 Representative chemical analyses of robinsonite from Gemerská Poloma (in wt. \%)

\begin{tabular}{|c|c|c|c|c|c|c|c|c|c|c|c|c|c|c|c|}
\hline \multirow[b]{2}{*}{$\mathrm{Pb}$} & \multicolumn{2}{|c|}{ GPX3 } & \multicolumn{3}{|c|}{ GPN1 } & \multicolumn{2}{|c|}{ GPN2 } & \multicolumn{3}{|c|}{ GPN3 } & \multicolumn{2}{|c|}{ GPN5 } & \multicolumn{3}{|c|}{ GPN6 } \\
\hline & 38.59 & 38.33 & 39.68 & 39.98 & 38.93 & 39.71 & 39.88 & 37.53 & 39.54 & 38.36 & 40.52 & 40.35 & 41.28 & 41.40 & 40.56 \\
\hline $\mathrm{Cu}$ & 0.00 & 0.00 & 0.00 & 0.00 & 0.00 & 0.00 & 0.00 & 0.00 & 0.07 & 0.00 & 0.00 & 0.10 & 0.00 & 0.00 & 0.00 \\
\hline $\mathrm{Fe}$ & 0.00 & 0.00 & 0.00 & 0.00 & 0.00 & 0.00 & 0.00 & 0.00 & 0.00 & 0.00 & 0.00 & 0.00 & 0.00 & 0.11 & 0.00 \\
\hline $\mathrm{Sb}$ & 25.37 & 25.31 & 30.22 & 31.27 & 28.48 & 30.81 & 31.83 & 22.14 & 30.05 & 25.98 & 33.43 & 32.39 & 36.75 & 35.56 & 34.36 \\
\hline $\mathrm{Bi}$ & 15.90 & 16.05 & 9.48 & 8.45 & 12.66 & 9.29 & 7.77 & 20.33 & 10.68 & 15.30 & 5.88 & 6.77 & 1.34 & 3.00 & 4.27 \\
\hline S & 20.12 & 20.11 & 20.70 & 20.99 & 20.81 & 20.96 & 20.63 & 19.72 & 20.30 & 19.92 & 20.24 & 20.47 & 20.46 & 20.13 & 20.47 \\
\hline $\mathrm{Cl}$ & 0.00 & 0.00 & 0.05 & 0.00 & 0.00 & 0.00 & 0.00 & 0.00 & 0.00 & 0.07 & 0.00 & 0.00 & 0.00 & 0.00 & 0.00 \\
\hline total & 99.98 & 99.79 & 100.13 & 100.69 & 100.88 & 100.77 & 100.12 & 99.72 & 100.64 & 99.63 & 100.07 & 100.09 & 99.83 & 100.20 & 99.66 \\
\hline$\overline{\mathrm{Pb}}$ & 3.901 & 3.879 & 92 & 77 & & 3. & & & 99 & 89 & 82 & & 4 & 46 & 3.961 \\
\hline $\mathrm{Cu}$ & 0.000 & 0.000 & 0.000 & 0.000 & 0.000 & 0.000 & 0.000 & 0.000 & 0.023 & 0.000 & 0.000 & 0.031 & 0.000 & 0.000 & 0.000 \\
\hline $\mathrm{Fe}$ & 0.000 & 0.000 & 0.000 & 0.000 & & 0.000 & & 0.000 & 0.000 & 0.000 & 0.000 & & & 0.040 & 0.000 \\
\hline$\Sigma$ & 3.901 & 3.879 & 3.892 & 3.877 & 3.820 & 3.857 & 3.902 & 3.874 & 3.931 & 3.889 & 3.982 & 3.984 & 4.000 & 4.086 & 3.961 \\
\hline $\mathrm{Sb}$ & 4.364 & 4.359 & 5.042 & 5.160 & & 5.093 & 5.300 & 3.890 & 5.055 & 4.482 & 5.591 & & 6.060 & 5.913 & 5.710 \\
\hline $\mathrm{Bi}$ & 1.594 & 1.611 & 0.922 & 0.812 & 1.232 & 0.895 & 0.754 & 2.081 & 1.047 & 1.538 & 0.573 & 0.657 & 0.129 & 0.291 & 0.413 \\
\hline$\Sigma$ & 5.968 & 5.970 & 5.964 & 5.972 & 5.987 & 5.988 & 6.054 & 5.971 & 6.102 & 6.020 & 6.164 & 6.057 & 6.189 & 6.204 & 6.123 \\
\hline $\bar{S}$ & 13.141 & 13.151 & 13.116 & 13.151 & 13.194 & 13.155 & 13.043 & 13.155 & 12.967 & 13.049 & 12.854 & 12.958 & 12.811 & 12.711 & 12.916 \\
\hline $\mathrm{Cl}$ & 0.000 & 0.000 & 0.028 & 0.000 & 0.000 & 0.000 & 0.000 & 0.000 & 0.000 & 0.041 & 0.000 & 0.000 & 0.000 & 0.000 & 0.000 \\
\hline
\end{tabular}

calculated empirical formulae are based on sum of all atoms $=23 \mathrm{apfu}$ 
Tab. 6 Representative chemical analyses of jamesonite from Gemerská Poloma (in wt. \%)

\begin{tabular}{|c|c|c|c|c|c|c|c|c|c|c|c|c|c|c|c|}
\hline \multirow[b]{2}{*}{$\mathrm{Pb}$} & \multirow{2}{*}{$\frac{\text { GPES5 }}{37.20}$} & \multirow{2}{*}{$\frac{\text { GPES9 }}{38.86}$} & \multirow{2}{*}{$\frac{\mathrm{GPX} 2}{36.82}$} & \multirow{2}{*}{$\frac{\text { GPX3 }}{37.71}$} & \multicolumn{2}{|c|}{ GPN2 } & \multicolumn{2}{|c|}{ GPN5 } & \multicolumn{2}{|c|}{ GPN6 } & \multirow{2}{*}{$\frac{\text { GPN7 }}{39.02}$} & \multirow{2}{*}{$\frac{\text { GPN8 }}{39.06}$} & \multicolumn{2}{|c|}{ GPA3 } & \multirow{2}{*}{$\begin{array}{c}\text { GPA4 } \\
38.47\end{array}$} \\
\hline & & & & & 37.85 & 37.92 & 38.09 & 38.75 & 39.22 & 39.71 & & & 38.37 & 38.76 & \\
\hline $\mathrm{Cu}$ & 0.14 & 0.09 & 0.31 & 0.17 & & & & & & & 0.00 & 0.00 & 0.02 & & 0.12 \\
\hline 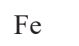 & & & & & & & & & & & & & & & .39 \\
\hline 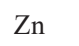 & & & & & & & & & & & & & & & .00 \\
\hline d & & & & & & & & & & & & & & & 0.00 \\
\hline U & .85 & 30.80 & 63 & 28.06 & 31.18 & & 32.29 & & 34 & & 96 & .14 & 35.38 & 55 & 34.94 \\
\hline 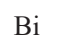 & & & & 11.34 & & & & & & & 1.69 & .17 & & & 2.51 \\
\hline & .79 & 21.91 & 37 & 21.18 & 2 & 21. & 21.12 & & 21.18 & & & .22 & & & 21.89 \\
\hline 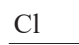 & .00 & & 00 & 0.05 & & & 0.00 & & 0.00 & 0.00 & 0.00 & 0.00 & 0.00 & 0.00 & 0.00 \\
\hline otal & 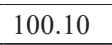 & 10 & & 100.74 & & 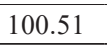 & 99.96 & 100 & 99.96 & & & & 99.55 & & 0.32 \\
\hline $\mathrm{b}$ & 81 & 1 & 302 & 3885 & 861 & 3 & 3890 & & 3071 & 2 & 3.905 & 057 & & 843 & 3.830 \\
\hline 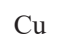 & & & & & & & & & & & & & & & \\
\hline e & 890 & 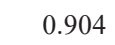 & 95 & & 0 & & & & & & & 49 & & & .884 \\
\hline n & & & & & & & & & & & & & & & \\
\hline $\mathrm{Cd}$ & 0.000 & 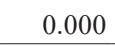 & 00 & & & & & & & & & & & & 0.000 \\
\hline & 819 & & 703 & 4 & 4.7 & & 4.8 & 4 & 4. & 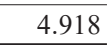 & 40 & .906 & 56 & 70 & 4.754 \\
\hline $\mathrm{Sb}$ & 4.944 & 5.281 & 4.856 & 4.920 & & & & & & & & & & & 5.919 \\
\hline $\mathrm{Bi}$ & 1.223 & 0.606 & 1.181 & 1.158 & 0.709 & 0.743 & 0.590 & 17 & 0.221 & 89 & 0.168 & 319 & 14 & 128 & 0.248 \\
\hline & 6.167 & & 037 & & & & & & & & & .204 & & & 6.167 \\
\hline & 14.015 & 14.263 & 14.260 & 14.096 & 14.087 & 14.116 & 13.939 & 13.783 & 13.861 & 13.867 & 14.038 & 13.891 & 14.155 & 14.103 & 14.080 \\
\hline 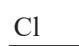 & 0.000 & 0.000 & 0.000 & 0.029 & 0.000 & 0.000 & 0.000 & 0.000 & 0.000 & 0.000 & 0.000 & 0.000 & 0.000 & 0.000 & 0.000 \\
\hline
\end{tabular}

calculated empirical formulae are based on sum of all atoms $=25 \mathrm{apfu}$

tuting for Sb (Fig. 10). Pažout (2020) recently solved the crystal structure of Bi-rich jamesonite from Kutná Hora and confirmed that $\mathrm{Bi}$ content is distributed over all three sites occupied by $\mathrm{Sb}$ without any preferential placement of $\mathrm{Bi}$ into one of the three $\mathrm{Sb}$ sites. Other minor elements detected in jamesonite are $\mathrm{Cu}$ (up to 0.11 apfu), $\mathrm{Zn}$ (up to $0.04 \mathrm{apfu}$ ), Cd (up to $0.03 \mathrm{apfu}$ ) and locally also $\mathrm{Cl}$ (up to 0.03 apfu).

\subsection{Rouxelite}

Rouxelite is very rare. It forms subhedral to anhedral grains up to $80 \mu \mathrm{m}$ (Fig. 13) directly associated with Bi-rich robinsonite, Bi-rich jamesonite and galena in quartz veins hosted in porphyric granite. Quantitative chemical analyses and the corresponding calculated empirical formulae of rouxelite from Gemerská Poloma

Tab. 7 Chemical composition of rouxelite from Gemerská Poloma (in wt. \%)

\begin{tabular}{|c|c|c|c|c|c|c|c|c|c|c|c|c|}
\hline \multirow[b]{2}{*}{$\mathrm{Pb}$} & \multicolumn{12}{|c|}{ GPN5 } \\
\hline & 43.46 & 43.94 & 43.50 & 43.86 & 44.00 & 43.79 & 44.27 & 44.31 & 44.12 & 44.31 & 43.86 & 43.30 \\
\hline $\mathrm{Ag}$ & 0.14 & 0.19 & 0.14 & 0.16 & 0.20 & 0.17 & 0.17 & 0.21 & 0.17 & 0.16 & 0.19 & 0.22 \\
\hline $\mathrm{Hg}$ & 1.11 & 1.37 & 1.48 & 1.25 & 1.29 & 1.25 & 1.26 & 1.40 & 1.33 & 1.34 & 1.31 & 1.33 \\
\hline $\mathrm{Cu}$ & 1.16 & 1.17 & 1.17 & 1.16 & 1.15 & 1.17 & 1.18 & 1.16 & 1.18 & 1.15 & 1.12 & 1.18 \\
\hline $\mathrm{Fe}$ & 0.06 & 0.00 & 0.00 & 0.00 & 0.06 & 0.00 & 0.06 & 0.00 & 0.05 & 0.00 & 0.00 & 0.00 \\
\hline $\mathrm{Sb}$ & 27.67 & 27.83 & 27.64 & 27.73 & 28.69 & 28.31 & 28.61 & 28.40 & 28.56 & 27.94 & 28.26 & 27.57 \\
\hline $\mathrm{Bi}$ & 6.16 & 6.27 & 6.30 & 6.33 & 5.31 & 5.97 & 5.31 & 5.23 & 5.37 & 5.64 & 5.84 & 6.24 \\
\hline $\mathrm{S}$ & 19.79 & 19.56 & 19.65 & 19.71 & 19.48 & 19.81 & 19.76 & 19.49 & 19.44 & 19.64 & 19.60 & 19.80 \\
\hline total & 99.55 & 100.33 & 99.88 & 100.20 & 100.18 & 100.47 & 100.62 & 100.19 & 100.22 & 100.18 & 100.17 & 99.64 \\
\hline$\overline{\mathrm{Cu}}$ & 1.964 & 1.961 & 1.975 & 1.952 & 1.915 & 1.959 & 1.962 & 1.940 & 1.965 & 1.934 & 1.881 & 1.998 \\
\hline $\mathrm{Fe}$ & 0.116 & 0.000 & 0.000 & 0.000 & 0.114 & 0.000 & 0.114 & 0.000 & 0.095 & 0.000 & 0.000 & 0.000 \\
\hline$\Sigma$ & 2.079 & 1.961 & 1.975 & 1.952 & 2.029 & 1.959 & 2.076 & 1.940 & 2.060 & 1.934 & 1.881 & 1.998 \\
\hline$\overline{\mathrm{Hg}}$ & 0.595 & 0.727 & 0.791 & 0.666 & 0.681 & 0.662 & 0.664 & 0.740 & 0.702 & 0.712 & 0.695 & 0.714 \\
\hline $\mathrm{Ag}$ & 0.140 & 0.188 & 0.139 & 0.159 & 0.196 & 0.165 & 0.167 & 0.203 & 0.167 & 0.156 & 0.185 & 0.219 \\
\hline$\Sigma$ & 0.735 & 0.915 & 0.930 & 0.825 & 0.877 & 0.827 & 0.830 & 0.943 & 0.868 & 0.868 & 0.880 & 0.933 \\
\hline $\mathrm{Pb}$ & 22.566 & 22.586 & 22.516 & 22.633 & 22.472 & 22.464 & 22.578 & 22.703 & 22.532 & 22.824 & 22.546 & 22.489 \\
\hline$\overline{\mathrm{Sb}}$ & 24.449 & 24.343 & 24.346 & 24.351 & 24.934 & 24.711 & 24.830 & 24.758 & 24.821 & 24.493 & 24.719 & 24.367 \\
\hline $\mathrm{Bi}$ & 3.171 & 3.195 & 3.233 & 3.239 & 2.689 & 3.039 & 2.685 & 2.655 & 2.719 & 2.880 & 2.975 & 3.213 \\
\hline$\Sigma$ & 27.620 & 27.538 & 27.579 & 27.590 & 27.623 & 27.750 & 27.516 & 27.413 & 27.540 & 27.373 & 27.694 & 27.580 \\
\hline S & 66.397 & 64.966 & 65.722 & 65.723 & 64.286 & 65.676 & 65.120 & 64.520 & 64.152 & 65.356 & 65.093 & 66.449 \\
\hline
\end{tabular}

calculated empirical formulae are based on sum of $M e=53 \mathrm{apfu}$ 
are shown in Tab. 7. Elevated contents of Ag (up to 0.22 apfu), which substitutes for $\mathrm{Hg}$ (Fig. 14a) as well as minor amounts of $\mathrm{Fe}$ (up to $0.12 \mathrm{apfu}$ ) were detected. The presence of significant contents of Bi (ranging from 2.66 to 3.24 apfu) substituting for Sb (Fig. 14b) is a characteristic feature of rouxelite from Gemerská Poloma, whereas no Bi was detected in rouxelite from
Buca della Vena and Magurka (Orlandi et al. 2005) or Kl'ačianka (Sejkora et al. 2021) and rouxelite from Monte Arsicio (Biagioni et al. 2014) shows only minor bismuth enrichment (up to 0.03 apfu). The mean $(n=12)$ empirical formula of studied rouxelite based on $\Sigma M e=53 \mathrm{apfu}$ is $\left(\mathrm{Cu}_{1.95} \mathrm{Fe}_{0.04}\right)_{\Sigma 1.99}\left(\mathrm{Hg}_{0.70} \mathrm{Ag}_{0.17}\right)_{\Sigma 0.87}$ $\mathrm{Pb}_{22.58}\left(\mathrm{Sb}_{24.59} \mathrm{Bi}_{2.97}\right)_{\Sigma 27.56} \mathrm{~S}_{65.28}$.
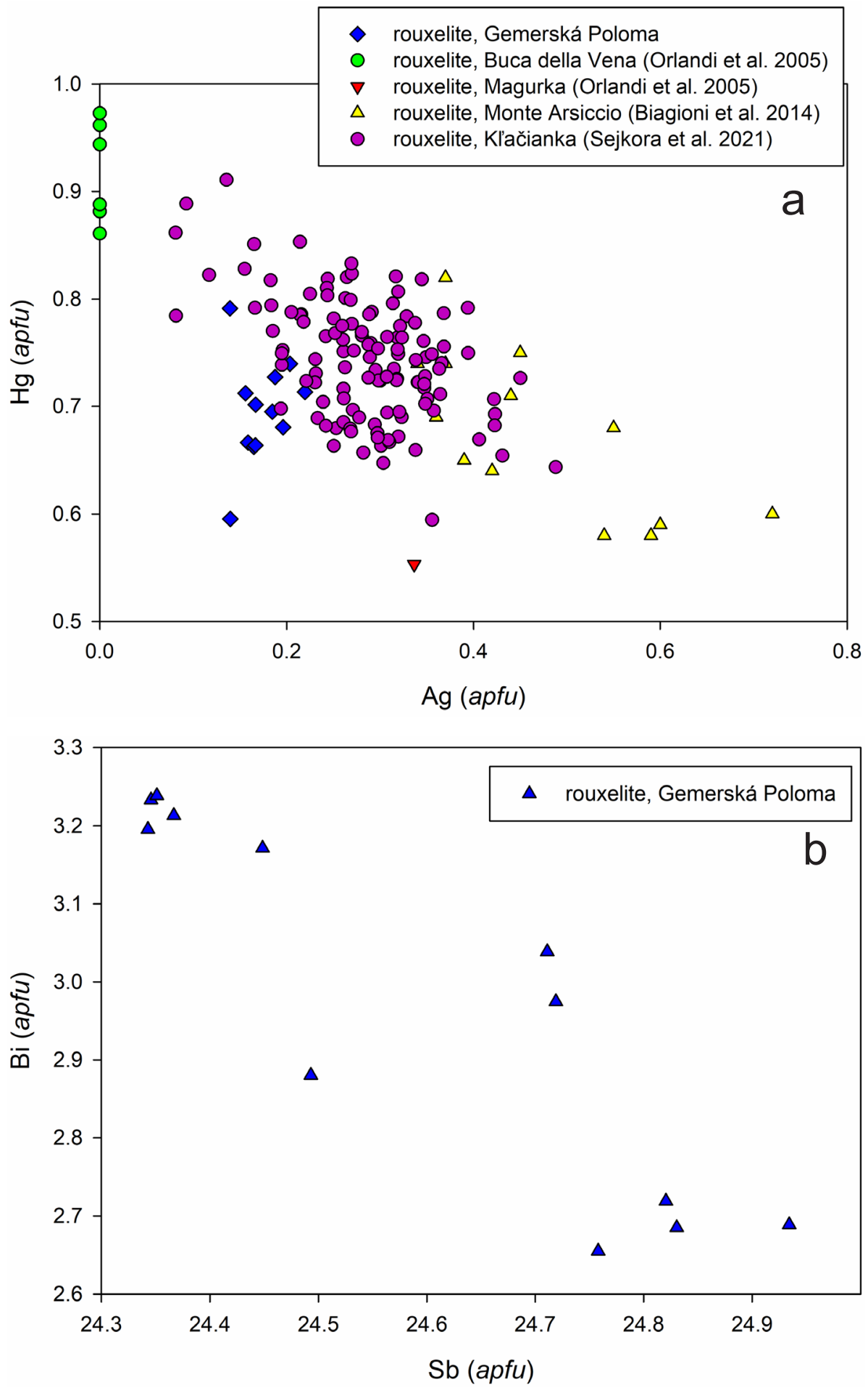

\subsection{Bournonite}

Bournonite was rarely found as anhedral grains and aggregates up to $40 \mu \mathrm{m}$ in size associated with tintinaite and galena (Fig. 15) in quartz veins hosted in porphyric granite. WDS analyses of bournonite from Gemerská Poloma are shown in Tab. 8. Besides of dominant contents of $\mathrm{Pb}, \mathrm{Cu}, \mathrm{Sb}$ and $\mathrm{S}$ only minor amounts of $\mathrm{Bi}$ (up to 0.03 apfu) were observed (Fig. 10). The mean $(n=7)$ empirical formula of studied bournonite based on the sum of all atoms $=6$ is $\mathrm{Pb}_{0.97} \mathrm{Cu}_{0.95}\left(\mathrm{Sb}_{1.02} \mathrm{Bi}_{0.02}\right)_{\Sigma 1.04} \mathrm{~S}_{3.04}$.

\subsection{Tetrahedrite group minerals (tetrahedrite-(Zn), tetrahedrite-(Fe))}

Minerals of the tetrahedrite group are very rare and occur only in quartz veins hosted in porphyric granite. They form anhedral grains and aggregates up to $7 \mathrm{~mm}$ in size embedded in quartz, closely associated with chalcopyrite and pyrite. Quantitative chemical analyses and the corresponding calculated empirical formulae of minerals of the tetrahedrite group from Gemerská Poloma are shown in Tab. 9. The trigonal position is predominantly occupied by $\mathrm{Cu}$ and only mi-

Fig. 14a - Variation of Ag vs. Hg contents $(a p f u)$ in rouxelite from Gemerská Poloma and other worldwide occurrences. $\mathbf{b}$ - Variation of $\mathrm{Sb}$ versus $\mathrm{Bi}$ contents $(a p f u)$ in rouxelite from $\mathrm{Ge}$ merská Poloma. 


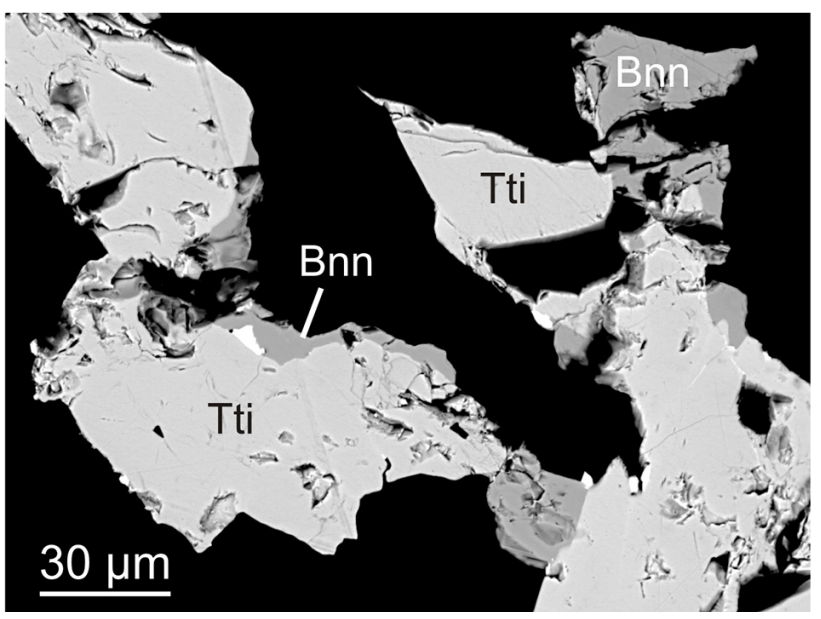

Fig. 15 Bournonite (Bnn) associated with tintinaite (Tti) and galena (white) in quartz (black). Sample GPA5, BSE image.

nor amounts of $\mathrm{Ag}$ (up to $0.10 \mathrm{apfu}$ ) are present. Zinc is a dominant element in the tetrahedral site (reaching up to 1.18 apfu), but $\mathrm{Fe}$ (reaching up to $1.16 \mathrm{apfu}$ ) is locally prevailing over $\mathrm{Zn}$ (Fig. 16), accompanied by only minor amounts of $\mathrm{Hg}$ (up to $0.05 a p f u$ ). Antimony is considerably prevailing (3.55-4.08 apfu) over As (0.03-0.58 apfu), so according to the recently published nomenclature scheme of minerals of the tetrahedrite group (Biagioni et al. 2020), the studied phases from Gemerská Poloma correspond to tetrahedrite-(Zn) and tetrahedrite- $(\mathrm{Fe})$.
Tab. 8 Chemical composition of bournonite from Gemerská Poloma (in wt. \%)

\begin{tabular}{lrrrrrrr}
\hline \multicolumn{7}{c}{ GPA5 } \\
\hline $\mathrm{Pb}$ & 41.38 & 41.74 & 41.71 & 41.15 & 41.29 & 40.82 & 41.62 \\
$\mathrm{Cu}$ & 12.47 & 12.39 & 12.07 & 12.45 & 12.46 & 12.22 & 12.43 \\
$\mathrm{Sb}$ & 25.88 & 25.59 & 25.21 & 25.91 & 25.62 & 24.80 & 25.80 \\
$\mathrm{Bi}$ & 0.06 & 0.98 & 1.19 & 0.25 & 0.53 & 1.14 & 0.71 \\
$\mathrm{~S}$ & 19.96 & 20.10 & 20.10 & 19.90 & 19.88 & 19.82 & 20.36 \\
\hline total & 99.75 & 100.80 & 100.28 & 99.66 & 99.78 & 98.81 & 100.91 \\
\hline $\mathrm{Pb}$ & 0.973 & 0.976 & 0.981 & 0.969 & 0.973 & 0.972 & 0.967 \\
$\mathrm{Cu}$ & 0.956 & 0.945 & 0.926 & 0.956 & 0.957 & 0.949 & 0.941 \\
\hline $\mathrm{Sb}$ & 1.036 & 1.018 & 1.009 & 1.039 & 1.028 & 1.004 & 1.020 \\
$\mathrm{Bi}$ & 0.001 & 0.023 & 0.028 & 0.006 & 0.012 & 0.027 & 0.016 \\
\hline $\mathrm{\Sigma}$ & 1.037 & 1.041 & 1.037 & 1.045 & 1.040 & 1.031 & 1.036 \\
\hline $\mathrm{S}$ & 3.033 & 3.038 & 3.056 & 3.030 & 3.029 & 3.049 & 3.056 \\
\hline
\end{tabular}

calculated empirical formulae are based on sum of all atoms $=6 \mathrm{apfu}$

\subsection{Origin and metallogenetic setting of the studied mineralization}

Bismuth (especially bismuthinite derivates and kobellite homologs) and lead-antimony sulfosalts (especially jamesonite, boulangerite or bournonite) are relatively common ore minerals at the siderite-type hydrothermal carbonate-quartz veins with sulfides hosted in Paleozoic (mostly Carboniferous) rocks in the Spišsko-gemerské rudohorie Mts. (e.g., Varček 1957; Kupčík et al. 1969; Grecula et al. 1995; Pršek 2008; Mikuš et al. 2018,

Tab. 9 Chemical composition of tetrahedrite-(Zn) and tetrahedrite-(Fe) from Gemerská Poloma (in wt. \%)

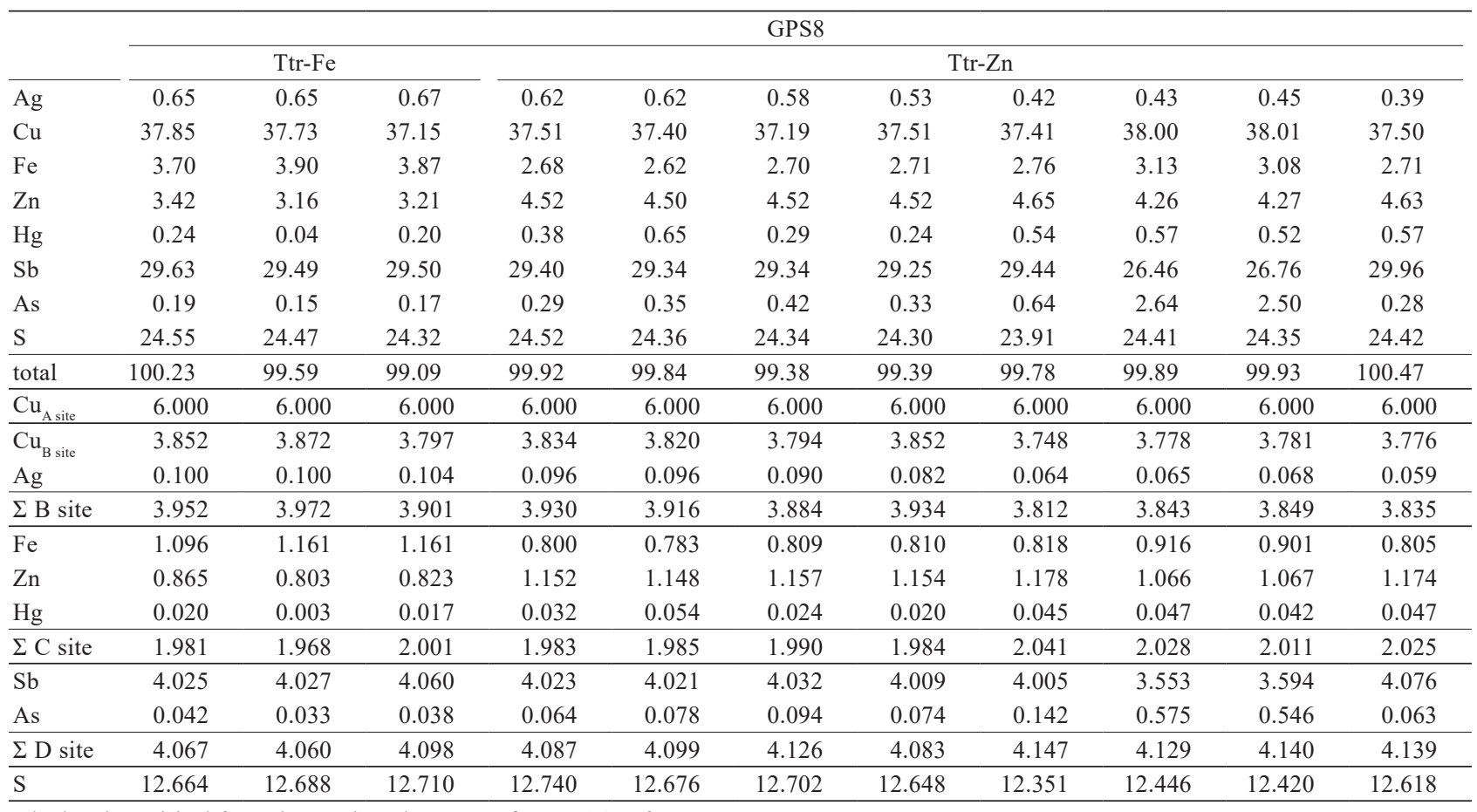

calculated empirical formulae are based on sum of $M e=16 \mathrm{apfu}$ 


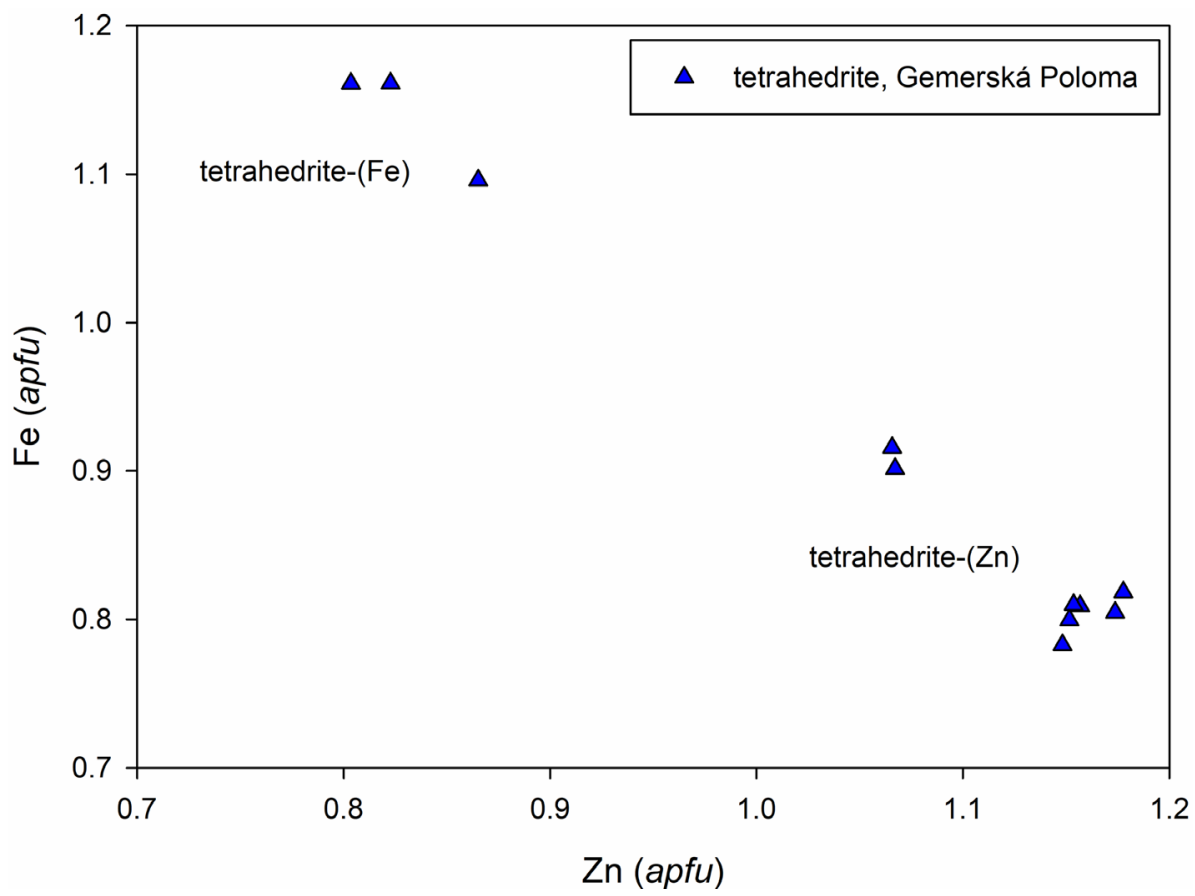

Fig. 16 Variation of $\mathrm{Zn}$ and Fe contents (apfu) in minerals of the tetrahedrite group from Gemerská Poloma.
2019). Although the studied association of sulfosalts from the hydrothermal quartz veins at the Gemerská Poloma has many similarities with the sulfosalt mineralization frequently developed at the siderite-type hydrothermal veins in the Gemeric unit, it represents considerably different and much older type of mineralization. Kohút and Stein (2005) confirmed the Permian ( $260 \mathrm{Ma})$ age of hydrothermal ore mineralization related to the Hnilec granite intrusion by Re/Os dating of molybdenite. In contrast, recent geochronological data from hydrothermal monazite (Hurai et al. 2015) or hydrothermal carbonates and gersdorffite (Kiefer et al. 2020) support the Cretaceous age of the siderite-type hydrothermal veins in the Gemeric unit. Moreover, bismuthinite, kobellite homologs and Bi-rich jamesonite were recently identified at hydrothermal U-Mo mineralization in Majerská valley near Čučma, also directly related to Permian Gemeric granites (Ferenc et al. 2021). Thus, the association of sulfosalts represented by bismuthinite, kobellite homologs and Bi-rich $\mathrm{Pb}-\mathrm{Sb}$ sulfosalts is not typical only for the siderite-type veins but also for the other, mineralogically different and older types of hydrothermal mineralization in the Gemeric unit.

The origin of the hydrothermal quartz veins with sulfosalts at the Gemerská Poloma is connected to the post-magmatic hydrothermal activity directly related with the intrusion of specialized, P-, F- and Li-enriched S-type Gemeric granites. This is supported by the fact that the studied veins are developed strictly in granitic rocks as well as by significantly different styles of mineralization with an abundant presence of fluorite or phosphates
(Števko et al. 2015) and locally also Nb-Ta minerals (Uher et al. 2009) or bastnäsite-(Ce) (Števko et al. 2020) and only minor presence of hydrothermal carbonates (Mn-rich siderite and minor dolomite). Hurai ed. (2007) studied fluid inclusions in quartz and fluorite from the hydrothermal quartz veins with sphalerite, galena and $\mathrm{Pb}-\mathrm{Sb}$ sulfosalt hosted in granite from the exploration drill hole VDD-14 located in Dlhá dolina near Gemerská Poloma. Homogenization temperatures of primary twophase $\mathrm{H}_{2} \mathrm{O}-\mathrm{CO}_{2}$ inclusions in quartz were $115-150{ }^{\circ} \mathrm{C}$ and $\mathrm{H}_{2} \mathrm{O}-\mathrm{NaCl}-\mathrm{CaCl}_{2}$ fluid inclusions in fluorite homogenized at $96-147^{\circ} \mathrm{C}$. The salinities varied substantially (from 3.1 to $35 \mathrm{wt} . \% \mathrm{NaCl}$ eq.), especially in fluid inclusions in fluorite. It can be assumed that the studied hydrothermal quartz veins with sulfosalts, fluorite and phosphates from Gemerská Poloma represent relatively low thermal, granite-related hydrothermal mineralization.

\section{Conclusions}

The hydrothermal quartz veins hosted in S-type Gemeric granites at Elisabeth mine near Gemerská Poloma contain an interesting and complex association of $\mathrm{Bi}, \mathrm{Pb}-\mathrm{Bi}$ and $\mathrm{Pb}-\mathrm{Sb}$ sulfosalts represented by bismuthinite derivates, minerals of kobellite homologous series, boulangerite, robinsonite, jamesonite, rouxelite, bournonite and minerals of the tetrahedrite group.

The two distinct types of sulfosalts associations were distinguished, each related to the different type of host rock and with variable $\mathrm{Bi} / \mathrm{Sb}$ ratio. The first one is represented predominantly by Bi-rich sulfosalts (bismuthinite 
derivates, kobellite, giessenite-izoklakeite) and it is characteristic for the quartz veins hosted in P-enriched leucogranite. In the second association, developed only in hydrothermal quartz veins hosted in porphyric granites, both $\mathrm{Bi}$ (bismuthinite derivates) as well as significant amounts of Sb-rich sulfosalts (tintinaite, boulangerite, robinsonite, jamesonite, rouxelite, bournonite and tetrahedrite-( $\mathrm{Zn})$ to tetrahedrite-( $\mathrm{Fe}))$ are present.

The origin of the hydrothermal quartz veins with sulfosalts at the Gemerská Poloma is connected to the postmagmatic hydrothermal activity directly related with the intrusion of Permian, specialized, S-type Gemeric granites.

Acknowledgements. This work was financially supported by the VEGA project $(2 / 0028 / 20)$ to MŠ and by the Ministry of Culture of the Czech Republic (DKRVO 2019-2023/1.II.c, 00023272) to JS. Both referees, Juraj Majzlan and Štefan Ferenc, as well as handling editor Jiří Zachariáš and editor-in-chief Jakub Plášil, are highly acknowledged for comments and suggestions that helped immensely to improve the manuscript.

Supplementary file with tables containing chemical analyses of bismuthinite derivates, kobellite-tintinaite series, giessenite-izoklakeite series, boulangerite, robinsonite and jamesonite is available online at the Journal web site (http://dx.doi.org/10.3190/jgeosci.328).

\section{References}

Armbruster T, Hummel W (1987) (Sb,Bi,Pb) ordering in sulfosalts: crystal-structure refinement of a Bi-rich izoklakeite. Amer Miner 72: 821-831

Bajaník Š, IvaničKa J, Mello J, Pristaš J, Reichwalder P, SNopko L, VozÁr J, VozÁrová A (1984) Geological map of the Slovenské Rudohorie Mts. - eastern part 1:50 000. Dionýz Štúr Institute of Geology, Bratislava

Biagioni C, MoËlo Y, Orlandi P (2014) Lead-antimony sulfosalts from Tuscany (Italy). XV. (Tl-Ag)-bearing rouxelite from Monte Arsiccio mine: occurrence and crystal chemistry. Mineral Mag 78: 651-661

Biagioni C, George Ll, Cook NJ, Makovicky E, Moëlo Y, Pasero M, Sejkora J, Stanley CJ, Welch MD, Bosi F (2020) The tetrahedrite group: Nomenclature and classification. Amer Miner 105(1): 109-122

Breiter K, Broska I, Uher P (2015) Intensive lowtemperature tectono-hydrothermal overprint of peraluminous rare-metal granite: a case study from the Dlhá dolina valley (Gemericum, Slovakia). Geol Carpath 66: $19-36$

BROSKA I, UHER P (2001) Whole-rock chemistry and genetic typology of the West-Carpathian Variscan granites. Geol Carpath 52: 79-90
BRosKa I, KuBIŠ M (2018) Accessory minerals and evolution of tin-bearing S-type granites in the western segment of the Gemeric Unit (Western Carpathians). Geol Carpath 59: 483-497

Crobanu CL, Cook NJ (2000) Intergrowths of bismuth sulphosalts from the Ocna de Fier Fe-skarn deposit, Banat, Southwest Romania. Eur J Mineral 12: 899-917 CooK NJ (1997) Bismuth and bismuth-antimony sulphosalts from Neogene vein mineralisation, Baia Borşa area, Maramureş, Romania. Mineral Mag 61: 387-409

Cook NJ, Ciobanu CL (2003) Lamellar minerals of the cuprobismutite series and related paderraite: A new occurrence and implications. Canad Mineral 41: 441-456

DiANIŠKa I, BreITER K, Broska I, KuBIŠ M, MalachovsKÝ $\mathrm{P}$ (2002) First phosphorous-rich $\mathrm{Nb}-\mathrm{Ta}-\mathrm{Sn}$-specialised granite from the Carpathians - Dlhá dolina valley granite pluton, Gemeric superunit. Geol Carpath 53: Special Issue (CD-ROM)

DianišKa I, Uher P, Hurai V, Huraiová M, Frank W, KONEČNÝ P, KRÁL J (2007) Mineralization of rare-metal granites. Pp. 254-330 In: HURAI V, ED. (2007) Sources of fluids and origin of mineralizations in the Gemeric unit. Open file report, Dionýz Štúr Institute of Geology, Bratislava, 1-365 (in Slovak)

DrnzíKová L, MANDÁKová K (1982) Mineralogy of tin and associated mineralizations in Hnilec ore field. Unpublished report, Geofond, 1-90 (in Slovak)

Ferenc Š, Š́tevko M, Mikuš T, MilovsKá S, Kopáčí R, Hoppanoví E (2021) Primary minerals and age of the hydrothermal quartz veins containing $\mathrm{U}-\mathrm{Mo}-(\mathrm{Pb}, \mathrm{Bi}$, $\mathrm{Te})$ mineralization in the Majerská valley near Čučma (Gemeric Unit, Spišsko-gemerské rudohorie Mts., Slovak Republic). Minerals 11: 629

GraSER S, HARRIS DC (1986) Giessenite from Giessen near Binn, Switzerland: New data. Canad Mineral 24: 19-20

Grecula P, Abonyi A, Abonyiová M, Antaš J, Bartalský B, Bartalský J, DianišKa I, Ďuña R, Gargulák M, GAZDAČKo L', HUdÁČEK J, KobUlskÝ J, LÖRINCZ L, Macko J, NÁvesŇÁK D, NÉMETH Z, NovotnÝ L, RADVANEC M, ROJKOVIČ I, ROZLOŽNÍK L, VARČEK C, ZLOCHA Z (1995) Mineral deposits of the Slovak Ore Mountains. Vol. 1. Geocomplex, Bratislava, 1-834

Harris DC, Roberts AC, Criddle AJ (1986) Izoklakeite, a new mineral species from Izok Lake, Northwest Territories. Canad Mineral 24: $1-5$

HURAI V, ED. (2007) Sources of fluids and origin of mineralizations in the Gemeric unit. Open file report, Dionýz Štúr Institute of Geology, Bratislava, 1-365 (in Slovak)

Hurai V, Paquette JL, Lexa O, KoneČný P, DianišKa I (2015) U-Pb-Th geochronology of monazite and zircon in albitite metasomatites of the Rožñava-Nadabula ore field (Western Carpathians, Slovakia): implications for the origin of hydrothermal polymetallic siderite veins. Mineral Petrol 109: 519-530 
JAMBOR JL, LACHANCE GR (1968) Bismuthian robinsonite. Canad Mineral 9: 426-428

Kiefer S, Števko M, Vojtko R, Ozdín D, Gerdes A, Creaser RA, Szczerba M, Majzlan J (2020) Geochronological constraints on the carbonate-sulfarsenide veins in Dobšiná, Slovakia: U/Pb ages of hydrothermal carbonates, $\mathrm{Re} / \mathrm{Os}$ age of gersdorffite, and $\mathrm{K} / \mathrm{Ar}$ ages of fuchsite. J Geosci 65: 229-247

KILÍK J (1997) Geological characteristic of the talc deposit in Gemerská Poloma-Dlhá dolina. Acta Montan Slovaca 2: 71-80 (in Slovak)

KoHÚt M, SteIN H (2005) Re-Os molybdenite dating of granite-related Sn-W-Mo mineralisation at Hnilec, Gemeric Superunit, Slovakia. Mineral Petrol 85: 117-129

KuBIŠ M, BRosKa I (2005) The role of boron and fluorine in evolved granitic rock systems (on the example of the Hnilec area, Western Carpathians). Geol Carpath 56: 193-204

KuBIŠ M, BrosKa I (2010) The granite system near Betliar village (Gemeric Superunit, Western Carpathians): evolution of a composite silicic reservoir. J Geosci 55: 131-148

KuPČ́́K V, SCHNEIDER A, VARČEK C (1969) Chemical composition of some Bi sulfosalts from the Spišsko-gemerské rudohorie Mts. Neu Jb Mineral, Mh 10: 445-454 (in German)

Makovicky E, Karup-Møller S (1986) New data on giessenite from the Bjørkåsen sulfide deposit at Otoften, northern Norway. Canad Mineral 24: 21-25

Makovicky E, MaKovicky M (1978) Representation of composition in the bismuthinite-aikinite series. Canad Mineral 16: 405-409

Makovicky E, Mumme WG (1986) The crystal structure of izoklakeite, $\mathrm{Pb}_{51.3} \mathrm{~S}_{20.4} \mathrm{Bi}_{19.5} \mathrm{Ag}_{1.2} \mathrm{Cu}_{2.9} \mathrm{~S}_{114}$ : the kobellite homologous series and its derivates. Neu Jb Mineral, Abh 153: 121-145

MALACHOVSKÝ P (1983) Mineralogy and paragenetic conditions of tin, rare metal and hydrothermal mineralization in Dlhá dolina. Unpublished report, Geofond, 1-146 (in Slovak)

Malachovský P, Jeleñ S, ĎuĎa R (1997) Minerals of indium from Gemerská Poloma-Dlhá dolina. Natura Carpat 38: 17-22 (in Slovak)

MalachovskÝ P, Uher P, ĎUĎA R (2000) Nb-W minerals in Dlhá valley rare-element granites, Spiš-Gemer Ore Mountains, Slovakia. Natura Carpat 41: 17-22 (in Slovak)

Mikuš T, Kondela J, JACKo S, MilovsKá S (2018) Garavellite and associated sulphosalts from the Strieborná vein in the Rožňava ore field (Western Carpathians). Geol Carpath 69: 221-236

Mikuš T, Bakos F, HöNIG S (2019) Bismuth sulphosalts from the siderite-sulphidic and As-Co mineralization in Medzev area, Slovakia. Ageos 11(2): 91-102

Moëlo Y, Roger G, Maurel-Palacin D, Marcoux E, Laroussi A (1995) Chemistry of some $\mathrm{Pb}-(\mathrm{Cu}, \mathrm{Fe})-$
( $\mathrm{Sb}, \mathrm{Bi})$ sulfosalts from France and Portugal. Implications for the crystal chemistry of lead sulfosalts in the $\mathrm{Cu}$-poor part of the $\mathrm{Pb}_{2} \mathrm{~S}_{2}-\mathrm{Cu}_{2} \mathrm{~S}-\mathrm{Sb}_{2} \mathrm{~S}_{3}-\mathrm{Bi}_{2} \mathrm{~S}_{3}$ system. Mineral Petrol 53: 229-250

MoËlo Y, Makovicky E, Mozgova NN, Jambor JL, Cook N, Pring A, Paar W, Nickel EH, Graeser S, KarupMøller S, Balic-Zunic T, Mumme WG, Vurro F, Topa D, Bindi L, Bente K, Shimizu M (2008) Sulfosalt systematics: a review. Report of the sulfosalt subcommittee of the IMA Commission on Ore Mineralogy. Eur J Mineral 20: 7-46

Orlandi P, Moëlo Y, Meerschaut A, Palvadeau P, Léone $P$ (2005) Lead-antimony sulfosalts from Tuscany (Italy). VIII. Rouxelite, $\mathrm{Cu}_{2} \mathrm{HgPb}_{22} \mathrm{Sb}_{28} \mathrm{~S}_{64}(\mathrm{O}, \mathrm{S})_{2}$, a new sulfosalt from Buca della Vena mine, Apuan Alps: definition and crystal structure. Canad Mineral 43: 919-933.

Ozawa T, Saitow A, Hori H (1998) Chemistry and crystallography of Bi-rich izoklakeite from the Otome mine, Yamanashi Prefecture, Japan and discussion of the izoklakeite-giessenite series. Mineral J 20: 179-187

PAžout R (2020) Distribution of $\mathrm{Bi}$ in the crystal structure of Bi-rich jamesonite, $\mathrm{FePb}_{4}\left(\mathrm{Sb}_{5.48} \mathrm{Bi}_{0.52}\right)_{\Sigma 6} \mathrm{~S}_{14}$. J Geosci 65: 261-265

Pažout R, SeJKora J, Šrein V (2017) Bismuth and bismuthantimony sulphosalts from Kutná Hora vein $\mathrm{Ag}-\mathrm{Pb}-\mathrm{Zn}$ ore district, Czech Republic. J Geosci 62: 59-76

Petrasová K, Faryad SW, Jeřábek P, ŽáčKová E (2007) Origin and metamorphic evolution of magnesite-talc and adjacent rocks near Gemerská Poloma, Slovak Republic. J Geosci 52: 125-132

Petrík I, Kohút M (1997) The evolution of granitoid magmatism during the Hercynian orogen in the Western Carpathians. In: Grecula P, Hovorka D, Putiš M (eds.) Geological Evolution of the Western Carpathians. Miner Slov Monogr 235-252

Petrík I, Kubiš M, KonečnÝ P, Broska I, Malachovský P (2011) Rare phosphates from the Surovec topaz-Li mica microgranite, Gemeric unit, Western Carpathians, Slovak Republic: Role of $\mathrm{F} / \mathrm{H}_{2} \mathrm{O}$ of the melt. Canad Mineral 49: 521-540

Poller U, Uher P, Broska I, Plašienka D, Janák M (2002) First Permian-Early Triassic zircon ages for tin-bearing granites from the Gemeric unit (Western Carpathians, Slovakia): connection to the post-collisional extension of the Variscan orogen and S-type granite magmatism. Terra Nova 14: 41-48

Pouchou JL, Pichoir F (1985) “PAP” $(\varphi \rho Z)$ procedure for improved quantitative microanalysis. In: ARMSTRONG JT (ed) Microbeam Analysis. San Francisco Press 104-106

PRŠEK J (2008) Chemical composition and crystal chemistry of $\mathrm{Bi}$ sulfosalts from the hydrothermal mineralizations hosted in crystalline basement of the Western Carpathians. Univerzita Komenského, Bratislava, 1-108 (in Slovak) 
PrŠEK J, MiKuš T (2006) Bi sulphosalts from the L'ubietováKolba occurrence. Miner Slov 38: 159-164

PrŠEK J, Ozdín D, SEJKora J (2008) Eclarite and associated $\mathrm{Bi}$ sulfosalts from the Brezno-Hviezda occurrence (Nízke Tatry Mts, Slovak Republic). Neu Jb Mineral, Abh 185: 117-130

Radvanec M, Gonda S (2019) Genetic model of Permian hydrothermal mineralization in Gemeric unit (W. Carpathians) from deep-seated zone of anatectic melting to volcanic-exhalative SedEx mineralization on surface. Miner Slov 52: 109-156

Radvanec M, KodĚra P, Prochaska W (2004) Mg replacement at the Gemerská Poloma talc-magnesite deposit, Western Carpathians, Slovakia. Acta Geol Sin 20: 773-790

RadVAnec M, KoneČnÝ P, OndREJKA M, Putiš M, Uher P, NÉmETH Z (2009) The Gemeric granites as an indicator of the crustal extension above the Late-Variscan subduction zone during the early Alpine riftogenesis (Western Carpathians): an interpretation from the monazite and zircon ages dated by CHIME and SHRIMP methods. Miner Slov 41: 381-394

SeJkora J, ŠTevko M, PrŠEK J, Litochleb J, Hovorič R, Makovicky E, Chovan M (2021) Unique association of sulfosalts from the Kl'ačianka occurrence, Nízke Tatry Mts., Slovak Republic. Minerals, 11, 1002

Števko M, SeJkora J (2017) Boulangerite and robinsonite from the Ochtiná-Č́žko baňa occurrence (Slovak Republic). Bull Mineral Petrolog 25: 273-276 (in Slovak)

Števko M, Uher P, Sejkora J, Malíková R, ŠKoda R, VACUlOVIČ T (2015) Phosphate minerals from the hydrothermal quartz veins in specialized S-type granites, Gemerská Poloma (Western Carpathians, Slovakia). J Geosci 60: 237-249

Števko M, Sejkora J, Uher P, Cámara F, Škoda R, VACUlovič T (2018) Fluorarrojadite-(BaNa), $\mathrm{BaNa}_{4} \mathrm{CaFe}_{13} \mathrm{Al}\left(\mathrm{PO}_{4}\right)_{11}\left(\mathrm{PO}_{3} \mathrm{OH}\right) \mathrm{F}_{2}$, a new member of the arrojadite group from Gemerská Poloma, Slovakia. Mineral Mag 82: 863-876
ŠTeVko M, SeJKora J, Dolníček Z (2020) Hydrothermal bastnäsite-(Ce) from the Elisabeth adit near Gemerská Poloma (Slovak Republic). Bull Mineral Petrolog 28: 1-8 (in Slovak)

Topa D, Makovicky E, PaAR WH (2002) Composition ranges and exsolution pairs for the members of the bismuthinite-aikinite series from Felbertal, Austria. Canad Mineral 40: 849-869

Uher P, Broska I (1996) Post-orogenic Permian granitic rocks in the Western Carpathian-Pannonian area: geochemistry, mineralogy and evolution. Geol Carpath 47: 311-321

Uher P, Malachovský P, Bačík P, Chudík P, ŠTevko M (2009) Polycrase-(Y), uranopolycrase a Ti-Nb-Ta-Fe mineral in quartz veins and exocontact zones of the Gemeric granites, the Slovak Ore Mountains. Bull mineralpetrolog Odd Nár Muz (Praha) 17: 14-24 (in Slovak)

VARČEK C (1957) Summary of paragenetic conditions of ore deposits in Gemer region. Geol Práce, Zoš 46: 107-131 (in Slovak)

Villaseñor G, Catlos EJ, Broska I, Kohút M, HrašKo L, Aguilera K, Etzel TM, Kyle R, Stockli DF (2021) Evidence for widespread mid-Permian magmatic activity related to rifting following the Variscan orogeny (Western Carpathians). Lithos (390-391): 106083

Voudouris PC, Spry PG, Mavrogonatos C, Sakellaris GA, Bristol SK, Melfos V, Fornadel AP (2013) Bismuthinite derivates, lillianite homologues, and bismuth sulfotellurides as indicators of gold mineralization in the Stanos shear-zone related deposit, Chalkidiki, northern Greece. Canad Mineral 51: 119-142

WAGNER T, Jonsson E (2001) Mineralogy of sulfosalt-rich vein-type ores, Boliden massive sulfide deposit, Skellefte District, Northern Sweden. Canad Mineral 39: 855-872

Xiang-Ping G, Wanatabe M, Ohkawa M, Hoshino K, Shibata Y, Desong C (2001) Felbertalite and related bismuth sulfosalts from the Feniushan copper skarn deposit, Nanjing, China. Canad Mineral 39: 1641-1652

ZAKrZEWSKI MA, MAKovicky E (1986) Izoklakeite from Vena, Sweden, and the kobellite homologous series. Canad Mineral 24: 7-18 